\title{
Temperature limits to deep subseafloor life in the Nankai Trough subduction zone
}

\author{
V. B. Heuer, ${ }^{1 *}$ F. Inagaki, ${ }^{2,3 *}$ Y. Morono, ${ }^{3 *}$ Y. Kubo, ${ }^{4, a}$ A. J. Spivack, ${ }^{5}$ B. Viehweger, ${ }^{1}$ T. Treude,${ }^{6} \mathrm{~F}$. \\ Beulig, ${ }^{7, b}$ F. Schubotz, ${ }^{1}$ S. Tonai, ${ }^{8}$ S. A. Bowden, ${ }^{9}$ M. Cramm, ${ }^{10}$ S. Henkel, ${ }^{11}$ T. Hirose, ${ }^{3}$ K. Homola, ${ }^{5}$ T. \\ Hoshino, ${ }^{3}$ A. Ijiri, ${ }^{3}$ H. Imachi, ${ }^{12}$ N. Kamiya, ${ }^{13, c}$ M. Kaneko, ${ }^{14}$ L. Lagostina, ${ }^{15, d}$ H. Manners, ${ }^{16}$ H.-L. \\ McClelland, ${ }^{17, e}$ K. Metcalfe, ${ }^{18}$ N. Okutsu, ${ }^{19, f}$ D. Pan, ${ }^{20,8}$ M. J. Raudsepp, ${ }^{21, h}$ J. Sauvage, ${ }^{5, i}$ M.-Y. Tsang, ${ }^{22}$ \\ D. T. Wang, ${ }^{23, j}$ E. Whitaker, ${ }^{24}$ Y. Yamamoto, ${ }^{25, k}$ K. Yang,${ }^{26, I}$ L. Maeda, ${ }^{4}$ R. R. Adhikari, ${ }^{1}$ C. Glombitza, ${ }^{27}$ Y. \\ Hamada, ${ }^{3}$ J. Kallmeyer, ${ }^{28}$ J. Wendt, ${ }^{1}$ L. Wörmer, ${ }^{1}$ Y. Yamada, ${ }^{2}$ M. Kinoshita, ${ }^{29}$ K.-U. Hinrichs ${ }^{1 \S}$ \\ *V.B.H, F.I., and Y.M. contributed equally to this work. \\ ${ }^{\S}$ Corresponding author: E-mail: khinrichs@uni-bremen.de (K.-U.H.)
}

One sentence summary: In deep subseafloor sediments above $45^{\circ} \mathrm{C}$ microbial cells are rare, endospores prevail, and life still persists at $120^{\circ} \mathrm{C}$.

${ }^{1}$ Center for Marine Environmental Sciences (MARUM), University of Bremen, Bremen, Germany

${ }^{2}$ Research and Development Center for Ocean Drilling Science (ODS), Japan Agency for Marine-Earth Science and Technology, Yokohama, Japan

${ }^{3}$ Kochi Institute for Core Sample Research (KCC), Japan Agency for Marine-Earth Science and Technology, Kochi, Japan

${ }^{4}$ Center for Deep Earth Exploration (CDEX), Japan Agency for Marine-Earth Science and Technology, Yokohama, Japan

${ }^{5}$ Graduate School of Oceanography, University of Rhode Island, Narragansett, USA

${ }^{6}$ Department of Earth, Planetary, and Space Sciences, Department of Atmospheric and Oceanic Sciences, University of California, Los Angeles (UCLA), Los Angeles, USA

${ }^{7}$ Center for Geomicrobiology, Department of Bioscience, Aarhus University, Aarhus, Denmark

${ }^{8}$ Faculty of Science and Technology, Kochi University, Kochi, Japan

${ }^{9}$ Department of Geology and Petroleum Geology, School of Geosciences, University of Aberdeen, Aberdeen, United Kingdom

${ }^{10}$ Department of Biological Sciences, University of Calgary, Calgary, Canada

${ }^{11}$ Alfred Wegener Institute, Helmholtz Centre for Polar and Marine Research, Bremerhaven, Germany

${ }^{12}$ Institute for Extra-cutting-edge Science and Technology Avantgarde Research, Japan Agency for Marine-Earth Science and Technology, Yokosuka, Japan

${ }^{13}$ Graduate School of Integrated Basic Sciences, Nihon University, Tokyo, Japan

${ }^{14}$ Geomicrobiology Research Group, National Institute of Advanced Industrial Science and Technology (AIST), Tsukuba, Japan

${ }^{15}$ Department of Environmental Systems Science, ETH Zürich, Zürich, Switzerland

${ }^{16}$ School of Geography, Earth and Environmental Sciences, Faculty of Science and Engineering, Plymouth University, Plymouth, United Kingdom

${ }^{17}$ Department of Earth and Planetary Sciences, Washington University in St. Louis, St. Louis, USA

${ }^{18}$ Division of Geological and Planetary Sciences, California Institute of Technology, Pasadena, USA 
${ }^{19}$ Atmosphere and Ocean Research Institute, University of Tokyo, Tokyo, Japan

${ }^{20}$ Department of Subsurface Geobiological Analysis and Research, Japan Agency for Marine-Earth Science and Technology, Yokosuka, Japan

${ }^{21}$ School of Earth Sciences, University of Queensland, St. Lucia, Australia

${ }^{22}$ Department of Earth Sciences, University of Toronto, Toronto, Canada

${ }^{23}$ Department of Earth, Atmospheric and Planetary Sciences, Massachusetts Institute of Technology, Cambridge, USA

${ }^{24}$ Department of Oceanography, Texas A\&M University, College Station, USA

${ }^{25}$ Department of Mathematical Science and Advanced, Technology (MAT), Japan Agency for MarineEarth Science and Technology, Yokosuka, Japan

${ }^{26}$ Department of Earth System Sciences, Yonsei University, Seoul, Republic of Korea

${ }^{27}$ Institute of Biogeochemistry and Pollutant Dynamics, ETH Zürich, Zürich, Switzerland

${ }^{28} \mathrm{Helmholtz}$ Centre Potsdam, GFZ German Research Centre For Geosciences, Potsdam, Germany

${ }^{29}$ Earthquake Research Institute, University of Tokyo, Tokyo, Japan

Present address:

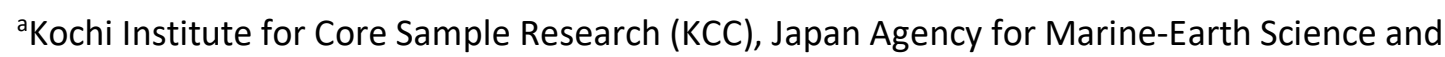
Technology, Kochi, Japan

${ }^{b}$ Department of Ecological Microbiology, University of Bayreuth, Bayreuth, Germany

'Graduate School of Engineering, Kyoto University, Kyoto, Japan

${ }^{\mathrm{d}}$ Robert Koch-Institut, Berlin, Germany

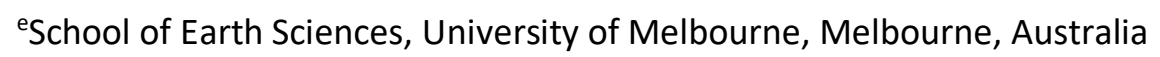

fInstitute for Marine-Earth Exploration \& Engineering, Japan Agency for Marine-Earth Science and Technology, Yokohama, Japan

${ }^{g}$ Department of Ecology \& Environmental Studies, The Water School, Florida Gulf Coast University, Fort Myers, USA

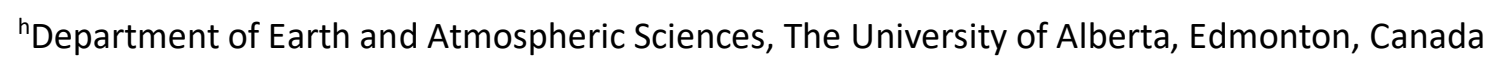
'Department of Marine Sciences, University of Gothenburg, Gothenburg, Sweden

'ExxonMobil, 22777 Springwoods Village Parkway, Spring, Texas 77389 USA

kGraduate School of Geoscience, Kobe University, Kobe, Japan

'Department of Oceanography, Pusan National University, Busan, Republic of Korea 
Abstract: Microorganisms in marine subsurface sediments substantially contribute to global biomass. Sediments warmer than $40^{\circ} \mathrm{C}$ account for half the volume of marine sediment, but the processes mediated by microbial populations in these hard-to-access environments are poorly understood. Here we demonstrate the presence and activity of microbial life in up to $1.2 \mathrm{~km}$ deep and up to $120^{\circ} \mathrm{C} \mathrm{hot}$ sediments in the Nankai Trough subduction zone. Above $45^{\circ} \mathrm{C}$, concentrations of vegetative cells drop two orders of magnitude, while endospores become more than 6,000 times more abundant than vegetative cells. Methane is biologically produced and oxidized until sediments reach $80-85^{\circ} \mathrm{C}$. In $100^{\circ} \mathrm{C}$ to $120^{\circ} \mathrm{C}$ hot sediments, isotopic evidence and elevated cell concentrations demonstrate the activity of acetate-degrading hyperthermophiles. Strikingly, above $45^{\circ} \mathrm{C}$ populated zones alternate with zones up to $192 \mathrm{~m}$ thick where microbes were undetectable.

Scientific ocean drilling has demonstrated the ubiquity of microbial life in deep subseafloor environments down to $2.5 \mathrm{~km}$ below seafloor (1-3). As sediment temperature increases with burial depth, more than $50 \%$ of the global marine sediment volume is situated above $40^{\circ} \mathrm{C}$ (4). So far, the vast majority of subseafloor-life studies has targeted environments with in-situ temperatures $<30^{\circ} \mathrm{C}$, and consequently the habitability of hotter sediments is largely unexplored. Microbes with growth temperatures up to $122^{\circ} \mathrm{C}$ have been isolated at hydrothermal vents (5), where the metabolism of these hyperthermophiles is fueled by high fluxes of oxidants and reductants (6). However, in deeply buried sediments, the potential metabolic energy is limited and with increasing depth and temperature the slow-growing microbial communities struggle to meet the cellular maintenance energy requirement $(3,7,8)$. Even in organic-matter rich petroleum reservoirs, microbial activity appears to cease at temperatures of $\sim 80^{\circ} \mathrm{C}(9,10)$.

Aiming to fill the vast knowledge gaps regarding the response of microbial life to increasing temperature, we investigated up to $1.2 \mathrm{~km}$ deep and up to $120^{\circ} \mathrm{C}$ hot sediments in the Nankai Trough off Cape Muroto, Japan (fig. S1). In this area, an up to 16 million year (My) old, 600 $\mathrm{m}$ thick succession of hemipelagic mudstones and tuffs has been rapidly buried by an equally thick layer of trench deposits over the past $\sim 0.4 \mathrm{My}(11,12$; fig. S2). Sediments concurrently heated by approximately $50^{\circ} \mathrm{C}$, and the onset of subduction formed a décollement separating the accreting and underthrusted domains $(11,12)$. First indications for the presence of microbial life in $\sim 800 \mathrm{~m}$ deep, $\sim 80-90^{\circ} \mathrm{C}$ warm sediments at a nearby drill site date back two decades $(12,13)$. However, insufficient sensitivity in cell detection at that time compromised the habitability assessment of this environment (13). We designed Expedition 370 of the International Ocean Discovery Program (IODP) to achieve maximal sensitivity in life detection together with accurate determination of in-situ temperatures, and established Site $\operatorname{Co0} 23\left(32^{\circ} 22.0018^{\prime} \mathrm{N}, 134^{\circ} 57.9844^{\prime} \mathrm{E}, 4776 \mathrm{~m}\right.$ water depth; fig. S1) in the vicinity of the previous drill site (14). Rigorous precautions during sampling and improvements in cell enumeration techniques (11) increased the sensitivity in cell detection by five orders of magnitude compared to the previous study (13). For the quantification of cells that can be stained by a fluorescent dye (hereafter termed vegetative cells; ref. 11), the procedural blank was $4.2 \pm 4.0$ cells $\mathrm{cm}^{-3}$ of sediment $\left(\mathrm{N}=20\right.$ ), thereby yielding a minimum quantification limit (MQL) of 16 cells $\mathrm{cm}^{-3}$ (11). Temperature measurements in the borehole constrained a steady-state temperature profile with a gradient of $110^{\circ} \mathrm{C} \mathrm{km}^{-1}$ and a temperature of $120 \pm 3^{\circ} \mathrm{C}$ in the deepest core retrieved from the basement at $1177 \mathrm{~m}$ below seafloor (mbsf) (11, figs. S3-4). The combination of authigenic minerals and thermally altered biomarkers reveals a history of episodic, short-term ingression of $\sim 140-220^{\circ} \mathrm{C}$ hot hydrothermal fluids along permeable strata in the underthrust domain (15, fig. S2).

At Site C0023, the depth profile of cell concentrations deviates notably from the global trend of gradually decreasing cell concentrations observed in similarly deep but substantially colder $\left(<30^{\circ} \mathrm{C}\right)$ sediments $(1,2)$. At $\sim 300-400 \mathrm{mbsf}$, concentrations of vegetative cells drop abruptly by two orders of 
magnitude and approach the MQL as temperature rises from $40^{\circ} \mathrm{C}$ to $50^{\circ} \mathrm{C}$ (Fig. $1 \mathrm{~A}$ ). Concurrently, concentrations of endospores, i.e., dormant, resistant structures affiliated with the bacterial phylum Firmicutes (fig. S5), which are widely found in marine sediments and soils $(16,17)$, increase to $2 \times 10^{5} \mathrm{~cm}^{-3}$ (Fig. 1B). Nevertheless, a small microbial population persists at $>50^{\circ} \mathrm{C}$ in the form of both vegetative cells and endospores (Fig. 1). Down to the $120^{\circ} \mathrm{C}$ hot basement, sediments harboring microbial communities with up to 400 vegetative cells $\mathrm{cm}^{-3}$ are interspersed within intervals of up to $192 \mathrm{~m}$ thickness, in which no cells were detected (Fig. 1A; fig. S6). We rule out the possibility that the detection of cells resulted from contamination because cell concentration is neither related to the abundance of fractures in sediment cores nor to the concentration of the perfluorocarbon-based contamination tracer supplied during drilling operation (11, fig. 57); such relationships would be expected if contaminant cells were introduced via drilling fluids. Consistent with the extremely low concentrations of vegetative cells and the difficulty of extracting DNA from endospores (18), DNA yields were insufficient for producing reliable DNA-based community data for samples buried more deeply than 320 mbsf (14). In samples shallower than 320 mbsf, the community resembled those found in shallow subsurface sediments (14).

In contrast to the scattered distribution of vegetative cells in sediments $>50^{\circ} \mathrm{C}$, endospores show a clear zonation (Fig. 1B), as quantified by measurement of the diagnostic biomarker dipicolinic acid (DPA) $(11,19)$. We rule out that substantial levels of DPA could have accumulated after the decay of endospores, given the propensity of 2-carboxylated pyridines to decarboxylate upon moderate shortterm heating (20). Endospore concentrations rise prominently in a $\sim 200-\mathrm{m}$ interval of $75-90^{\circ} \mathrm{C}$ hot sediments, with a maximum of $1.2 \times 10^{6}$ endospores $\mathrm{cm}^{-3}$ at $85^{\circ} \mathrm{C}$. The average endospore-tovegetative cell ratio exceeds 6,000 in sediments below 350 mbsf (11; table S1) and is thus 2-3 orders of magnitude higher than in cold subseafloor sediments (19). Plausible scenarios for the accumulation of endospores in sediments that are nearly barren of vegetative cells relate to the thermal history of the site since the onset of trench conditions $\sim 0.4 \mathrm{My}$ ago $(11,12)$ and involve the transitory growth of a thermophilic population of endospore formers (cf. ref. 17) after temperature rose to $\sim 50^{\circ} \mathrm{C}$ and its subsequent sporulation $(11$, fig. S8). Interestingly, in two expanded horizons, at 570-633 mbsf and 829-1021 mbsf, neither vegetative cells nor endospores were detected (Fig. 1, fig. S6).

Pore-water profiles of microbial substrates and products provide evidence for microbial activity down to the $\sim 16 \mathrm{My}$ old oceanic crust (Fig. 2). High concentrations of methane with a mean carbon isotopic composition $\left(\delta^{13} \mathrm{C}-\mathrm{CH}_{4}\right)$ of $-61.3 \pm 3.0$ per mil (\%) (Fig. $2 \mathrm{~A}-\mathrm{B}$ ) indicate biogenic methanogenesis at least down to the $80-85^{\circ} \mathrm{C}$ hot sulfate methane transition zone (SMTZ) at $~ 730$ mbsf. The positive excursion in $\delta^{13} \mathrm{C}_{-} \mathrm{CH}_{4}$ in the 80 to $85^{\circ} \mathrm{C}$ hot SMTZ (Fig. 2B) points to a biogenic methane sink and is consistent with previous observations from cultivation-based approaches that demonstrated the activity of thermophilic anaerobic methane-oxidizing communities at these temperatures (21-22). Below the SMTZ, methane is only present in micromolar concentrations, with rising $\delta^{13} \mathrm{C}-\mathrm{CH}_{4}$ values and decreasing methane/ethane ratios indicating a relative increase of thermogenic hydrocarbons (Fig. 2B). Remarkably, a reversal of this trend at $>1000$ mbsf hints at a biogenic methane source above $100^{\circ} \mathrm{C}$.

Diffusive profiles of pore-water constituents do not allow the distinction between current and recent in-situ biogeochemical processes, while radiotracer experiments specifically target on-going microbial activity, albeit with some unavoidable deviation from in-situ conditions. At Site $\mathrm{C0023}$, radiotracer experiments reveal present-day methanogenic activity in $65 \%$ of the investigated samples (Fig. 2D). Potential rates of methanogenesis via $\mathrm{CO}_{2}$ reduction in sediments below $300 \mathrm{mbsf}$ are generally below $4 \mathrm{pmol} \mathrm{cm}^{-3} \mathrm{~d}^{-1}$ and thus within the range of previous observations made in the deep 
subseafloor (23). Their depth distribution is consistent with cellular concentrations (Fig. 1) and activities deduced from the pore-water profiles of methane (Fig. 2A-B). Rates are highest in the methanic zone, decrease distinctly to $<0.6 \mathrm{pmol} \mathrm{cm}^{-3} \mathrm{~d}^{-1}$ below the SMTZ, and drop to undetectable levels in $63 \%$ of the samples taken from the deep expanded horizon with no detectable cells and endospores (Fig. 2D). Strikingly, potential methanogenesis rates rise again to values observed in the methanic zone in the three deepest samples (Fig. 2D), thus confirming the existence of active methanogenic communities in $110-120^{\circ} \mathrm{C}$ hot sediments and pillow basalts above basement.

Acetate has been suggested to fuel microbial life in deeply buried, geothermally heated sediments (24). Throughout the sediment column of Site $\mathrm{C} 0023$, reactions degrading acetate via sulfate reduction and methanogenesis are exergonic, with Gibbs free energy yields becoming increasingly negative with depth (fig. S9; ref. 11). The concentrations of acetate and its carbon isotopic compositions ( $\delta^{13} \mathrm{C}$-acetate) (Fig. $2 \mathrm{C}$ ) indicate distinct changes in acetate utilization with temperature and depth. In the up to $60^{\circ} \mathrm{C}$ hot upper $600 \mathrm{mbsf}$, low and invariable concentrations of acetate around $26 \pm 22 \mu \mathrm{M}(\mathrm{N}=19)$ imply its balanced microbial production and consumption, while the corresponding fluctuation of $\delta^{13} \mathrm{C}$-acetate around $-25.5 \pm 3.4 \%$ is consistent with various metabolic pathways influencing its pool (25). In sharp contrast, acetate utilization is minimal at $60^{\circ} \mathrm{C}$ to $100^{\circ} \mathrm{C}$. At $60-75^{\circ} \mathrm{C}$, acetate concentrations rise steeply with the simultaneous decline of methane concentrations and accumulation of endospores. A local minimum in acetate concentration at the SMTZ (Fig. 2C) is consistent with some microbial utilization at this geochemical interface. Below the SMTZ, acetate concentrations level at $9.2 \pm 2.4 \mathrm{mM}$ with an invariable $\delta^{13} \mathrm{C}$-acetate around $-18.8 \pm 0.5 \%$. The combination of high concentration and low isotopic variability implies an acetate pool without significant turnover within the endospore-dominated zone as well as in the underlying $200 \mathrm{~m}$ thick zone, where neither cells nor endospores were detected.

At $>1030 \mathrm{mbsf}$, however, acetate concentrations decline and $\delta^{13} \mathrm{C}$-acetate monotonically increases with depth, reaching a maximum of $-7.9 \%$ in the deepest pore-water sample recovered from $1101 \mathrm{mbsf}$. This trend is consistent with active hyperthermophiles degrading preferentially ${ }^{13} \mathrm{C}$ depleted acetate, leaving the residual acetate isotopically enriched. Without continued consumption, diffusion would homogenize $\delta^{13} \mathrm{C}$-acetate variations, as observed in the overlying sediments. The drawdown of the acetate pool requires isotopic fractionation factors of -7.7 to $-15.4 \%$ o (11, fig. S10), which are consistent with those observed in lab cultures (26). The size of the sink would have to be on the order of $5 \times 10^{-12} \mathrm{~mol} \mathrm{~cm}^{-3}$ year $^{-1}$ (11). Given cellular concentrations of 10 to $100 \mathrm{~cm}^{-3}$ in sediments corresponding to this acetate sink, the required cellular metabolic rates are 2-3 orders of magnitude lower than observed in lab cultures of the hyperthermophilic archaea Pyrococcus furiosus (27) and Archaeoglobus fulgidus (28). Thus, acetate profiles are consistent with the existence of a small acetate-utilizing microbial community at $>100^{\circ} \mathrm{C}$. Acetate oxidation and syntrophic consumption of the resulting $\mathrm{CO}_{2}$ and electrons by methanogens are a known acetate sink in deep sediments (29) and at elevated temperatures (30). This process is exergonic under in-situ conditions (fig. S9) and could account for the elevated methanogenesis rates (Fig. 2D) and the isotopic signature of methane (Fig. 2B) in the deepest portion of the borehole.

Our findings reveal the impact of increasing temperature with depth on microbial life. This is exemplified in the massive collapse of the population of vegetative cells in $<0.4$ My old sediments at $300-400 \mathrm{mbsf}$. In this interval, temperatures of $40-50^{\circ} \mathrm{C}$ are within the upper growth range of mesophiles. The coincident accumulation of endospores as a result of a putative sporulation of mesophilic endospore-forming Firmicutes (Fig. 1) supports the conclusion that the abundance and activity of microbial populations is primarily controlled by temperature-dependent physiological factors down to $600 \mathrm{mbsf}$. In the deeper portion of Site $\mathrm{C0023}$ geological processes exert additional 
control. A sharp decline in biogenic methanogenesis and acetate utilization at $70^{\circ} \mathrm{C}$ to $75^{\circ} \mathrm{C}$ coincides with the upper growth range of thermophiles, but notably, this depth interval concurrently spans the lithological boundary between Upper and Lower Shikoku Basin (cf. Fig. 1). At this boundary, tuffs (indurated volcanic ash) cease to be present. Tuff alteration forms smectite, and microbial reduction of $\mathrm{Fe}(\mathrm{III})$ in smectite serves as an energy yielding process and has in fact been found to promote smectite-to-illite conversion at 500-600 mbsf at Site C0023 (31). Thus, a modulation of the down-hole profile of microbial activity by microbe-mineral interactions is conceivable. Peak endospore concentrations at $85^{\circ} \mathrm{C}$ coincide with both the SMTZ and the plate boundary décollement. While frictional heating to temperatures of potentially up to $\sim 1000^{\circ} \mathrm{C}$ (32) during plate motion likely causes additional challenges for microorganisms in this zone, endospores and high acetate concentrations provide a seed bank and energy, respectively, for an ecosystem recovery from episodic perturbations.

In the upper $200 \mathrm{~m}$ of the underthrust domain, at $\sim 90-100^{\circ} \mathrm{C}$, an expanded zone without detectable cells and with no geochemical signs of microbial activity traverses the sparsely populated sediments (Figs. 1, 2). In this zone, under-compacted and mechanically weak sediments are overpressurized and affected by $\sim 145-220^{\circ} \mathrm{C}$ hot fluids for short durations $(15,33)$. The short heating events may have locally sterilized sediment (15), but microbial cells, acetate consumption and methanogenic activity prevail again in $>100^{\circ} \mathrm{C}$ sediments, where mechanical strength and salinity increase towards the sediment/basement interface (Figs. 1, 2, fig. S2). Hydraulic communication between basalts and overlying sediment is evidenced by shared styles of epigenetic mineralization in the form of calcite veins and ferruginous metal oxides. Mass transfer between basal sediment and a basalt-hosted aquifer, would increase the habitability of the basal sediment by reducing formation fluid pressure, and replenishing otherwise depleted substrates such as reduced iron and sulfate (34).

Our study reveals the dependence of microbial abundance and activity to critical temperatures around $40-50^{\circ} \mathrm{C}$ and $70^{\circ} \mathrm{C}$; it moreover shows that life in the deep subseafloor is not constrained by an upper temperature limit below $120^{\circ} \mathrm{C}$. Our findings highlight the interplay of geological processes, temperature and microbial life in the deep, hot sediments of the Nankai Trough, and suggest a critical influence of subduction-related geological processes on habitability. 
Acknowledgments. This research used samples and data provided by the International Ocean Discovery Program (IODP). The authors are grateful to IODP and the Ministry of Education, Culture, Sports, Science and Technology of Japan (MEXT) for providing an opportunity to explore the deep biosphere during Expedition 370. The expedition comprised simultaneous offshore and onshore work, conducted on the drilling vessel Chikyu and in the Kochi Core Center (KCC), respectively. We thank all operational and technical staff members who have put our plans into action onboard Chikyu and at KCC. In particular, we would like to thank N. Eguchi, M. Kyo, and I. Sawada for their knowledgeable support during project design, and T. Saruhashi and K. Aoike for care- and successful drilling operations. This is a contribution to the Deep Carbon Observatory (DCO).

Funding. This work was supported in part by the Japan Society for the Promotion of Science (JSPS) Strategic Fund for Strengthening Leading-Edge Research and Development (to JAMSTEC and F.I.), the JSPS Funding Program for Next Generation World-Leading Researchers (GR102 to F.I.), the Deutsche Forschungsgemeinschaft through projects 387745511 (to V.B.H.), 408178672 (to F.S.), grant 408249062 (to J.K.), grant 279667358 and Hi 616-14-1 (to K.-U.H.) and through the Cluster of Excellence "The Ocean Floor - Earth's Uncharted Interface" (project 390741603), the IODP U.S. Science Support Program (National Science Foundation prime award OCE-1450528 to T.T.), and the Natural Environment Research Council awards NE/P015182/1 and NE/R003408/1 (to S.A.B. and H.M., respectively). Additional support enabling this project was provided by the Deep Carbon Observatory.

Data availability. All shipboard and shore-based data presented in this manuscript are archived and publicly available online in the IODP Expedition 370 Proceedings (14), through the J-CORES database (http://sio7.jamstec.go.jp/j-cores.data/370/C0023A/) and the PANGAEA database (http://doi.pangaea.de/ 10.1594/xxxx).

Competing interests. None.

Obligatory IODP related key words: International Ocean Discovery Program, DV Chikyu, Expedition 370, Temperature Limit of the Deep Biosphere off Muroto, T-Limit, Site C0023. 


\section{References and Notes}

1. J. Kallmeyer, R. Pockalny, R. R. Adhikari, D. C. Smith, S. D'Hondt, Global distribution of microbial abundance and biomass in subseafloor sediment. Proc. Natl. Acad. Sci. U. S. A. 109, 16213-16216 (2012).

2. R. J. Parkes et al., A review of prokaryotic populations and processes in sub-seafloor sediments, including biosphere:geosphere interactions. Mar. Geol. 352, 409-425 (2014).

3. F. Inagaki et al., Exploring deep microbial life in coal-bearing sediment down to $\sim 2.5 \mathrm{~km}$ below the ocean floor. Science 349, 420-424 (2015).

4. D. E. LaRowe, E. Burwicz, S. Arndt, A. W. Dale, J. P. Amend, Temperature and volume of global marine sediments. Geology 45, 275-278 (2017).

5. K. Takai et al., Cell proliferation at 122 degrees $\mathrm{C}$ and isotopically heavy $\mathrm{CH}_{4}$ production by a hyperthermophilic methanogen under high-pressure cultivation. Proc. Natl. Acad. Sci. U. S. A. 105, 1094910954 (2008).

6. J. P. Amend, E. L. Shock, Energetics of overall metabolic reactions of thermophilic and hyperthermophilic Archaea and Bacteria. FEMS Microbiol. Rev. 25, 175-243 (2001).

7. M. A. Lever et al., Life under extreme energy limitation: a synthesis of laboratory- and field-based investigations. FEMS Microbiol. Rev. 39, 688-728 (2015).

8. M. H. Møller et al., D:L-amino acid modeling reveals fast microbial turnover of days to months in the subsurface hydrothermal sediment of Guaymas Basin. Front. Microbiol., 9, 967 (2018).

9. A. Wilhelms et al., Biodegradation of oil in uplifted basins prevented by deep-burial sterilization. Nature 411, 1034-1037 (2001).

10. I. M. Head, D. M. Jones, S. R. Larter, Biological activity in the deep subsurface and the origin of heavy oil. Nature 426, 344-352 (2003).

11. Materials and Methods are available as supplementary materials

12. B. Horsfield et al., Living microbial ecosystems within the active zone of catagenesis: Implications for feeding the deep biosphere. Earth Planet. Sci. Lett. 246, 55-69 (2006).

13. G. F. Moore, A. Taira, A. Klaus, and the Expedition 190 Scientists. Proceedings of the Ocean Drilling Program, Initial reports, 190. (Ocean Drilling Program, College Station, Texas, 2001). doi:10.2973/odp.proc.ir.190.2001

14. V. B. Heuer, F. Inagaki, Y. Morono, Y. Kubo, L. Maeda, and the Expedition 370 Scientists. Temperature Limit of the Deep Biosphere off Muroto. Proceedings of the International Ocean Discovery Program. 370, College Station, TX (International Ocean Discovery Program) (2017). https://doi.org/10.14379/iodp.proc.370.101.2017

15. M.-Y. Tsang et al., Hot fluids, burial metamorphism and thermal histories in the underthrust sediments at IODP 370 Site C0023, Nankai Accretionary Complex. Mar. Petr. Geol. 112, 104080 (2020).

16. T. Aüllo, A. Ranchou-Peyruse, B. Ollivier, M. Magot, Desulfotomaculum spp. and related gram-positive sulfatereducing bacteria in deep subsurface environments. Front. Microbiol. 4, 362 (2013).

17. C. Hubert et al., A constant flux of diverse thermophilic bacteria into the cold Arctic seabed. Science 325, 1541-1544 (2009).

18. S. Filippidou, T. Junier, T. Wunderlin, C. C. Lo, P. E. Li, P. S. Chain, P. Junier, Under-detection of endosporeforming Firmicutes in metagenomic data. Comput. Struct. Biotechnol. J. 13, 299-306 (2015).

19. L. Wörmer et al., Microbial dormancy in the marine subsurface: Global endospore abundance and response to burial. Sci. Adv. 5, eaav1024 (2019). 
20. A. R. Katritzky, A. R. Lapucha, M. Siskin, Aqueous high-temperature chemistry of carbo- and heterocycles. 3. 2substitutes pyridines. Energy Fuels 4, 506-510 (1990).

21. J. Kallmeyer, A. Boetius, Effects of temperature and pressure on sulfate reduction and anaerobic oxidation of methane in hydrothermal sediments of Guaymas Basin. Appl. Environ. Microbiol., 70, 231-1233 (2004).

22. T. Holler et al., Thermophilic anaerobic oxidation of methane by marine microbial consortia. ISME J. 5, 19461956 (2011).

23. R. J. Parkes, B. A. Cragg, P. Wellsbury, P., Recent studies on bacterial populations and processes in subseafloor sediments: a review. Hydrogeol. J., 8, 11-28 (2000).

24. P. Wellsbury et al., Deep marine biosphere fuelled by increasing organic matter availability during burial and heating. Nature 388, 573-576 (1997).

25. V. B. Heuer, J. W. Pohlman, M. E. Torres, M. Elvert, K.-U. Hinrichs, The stable carbon isotope biogeochemistry of acetate and other dissolved carbon species in deep subseafloor sediments at the northern Cascadia Margin. Geochim. Cosmochim. Acta 73, 3323-3336 (2009).

26. D. Goevert, R. Conrad, Stable carbon isotope fractionation by acetotrophic sulfur-reducing bacteria. FEMS Microbiol. Ecol. 71, 218-225 (2010).

27. S. H. Brown, R. M. Kelly, Cultivation techniques for hyperthermophilic archaebacteria - continuous culture of Pyrococcus Furiosus at temperatures near 100-degrees-C. Appl. Environ. Microbiol. 55, 2086-2088 (1989).

28. D. E. Canfield, K. S. Habicht, B. O. Thamdrup, The Archean sulfur cycle and the early history of atmospheric oxygen. Science 288, 658-661 (2000).

29. F. Beulig, H. Roy, C. Glombitza, B. B. Jorgensen, Control on rate and pathway of anaerobic organic carbon degradation in the seabed. Proc. Natl. Acad. Sci. U. S. A. 115, 367-372 (2018).

30. S. H. Zinder, M. Koch, Non-aceticlastic methanogenesis from acetate: acetate oxidation by a thermophilic syntrophic coculture. Arch. Microbiol. 138, 263 - 272 (1984).

31. J. Kim et al. Naturally occurring, microbially induced smectite-to-illite reaction. Geology 47, 535-539 (2019).

32. P. M. Fulton et al., Low coseismic friction on the Tohoku-Oki Fault determined from temperature measurements. Science 342, 1214-1217 (2013).

33. Y. Hamada et al., In-situ mechanical weakness of subducting sediments beneath a plate boundary décollement in the Nankai Trough. Progress in Earth and Planetary Science 5, 70 (2018).

34. M. E. Torres et al., Crustal fluid and ash alteration impacts on the biosphere of Shikoku Basin sediments, Nankai Trough, Japan. Geobiology 13, 562-580 (2015).

\section{Supplementary Materials:}

www.sciencemag.org/content/\#\#\#

Materials and Methods and Supporting Text

Figs. S1 to S10

Tables S1 to S2

References (35-81) 


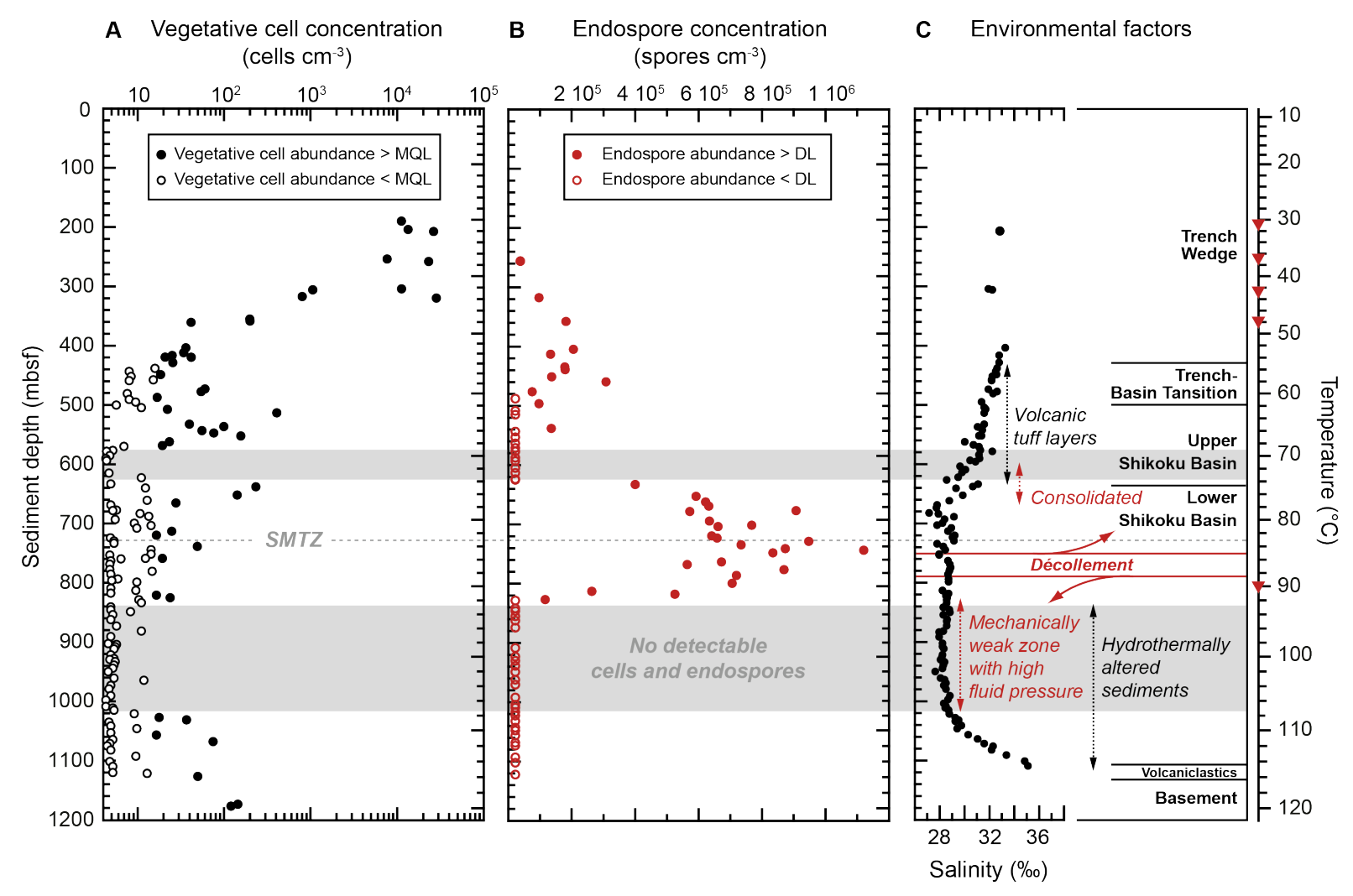

Fig. 1. Depth profiles of vegetative cells and endospores in relation to environmental factors at IODP Site $\mathbf{C 0 2 3}$. (A) Concentrations of vegetative cells determined by counting of microbial cells fluorescently stained with SYBR Green I; based on a procedural blank of $4.2 \pm 4.0$ cells $\mathrm{cm}^{-3}$ of sediment $(N=20)$, the

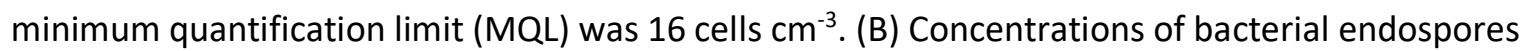
derived from the diagnostic biomarker dipicolinic acid; analytical sensitivity corresponds to a detection limit (DL) of $2.2 \times 10^{4}$ endospores $\mathrm{cm}^{-3}$. (C) A schematic summary of environmental factors such as temperature, tectonic units, and salinity showing the geochemical influence of basalt alteration in the basement; red symbols on the temperature axis designate the depth horizons at which in-situ temperature measurements were made (11). Gray shading indicates zones where concentrations of both vegetative cells and endospores were below the detection limits of the employed methods in all investigated samples; SMTZ indicates the location of the sulfate-methane transition zone (cf. Fig. 2). 


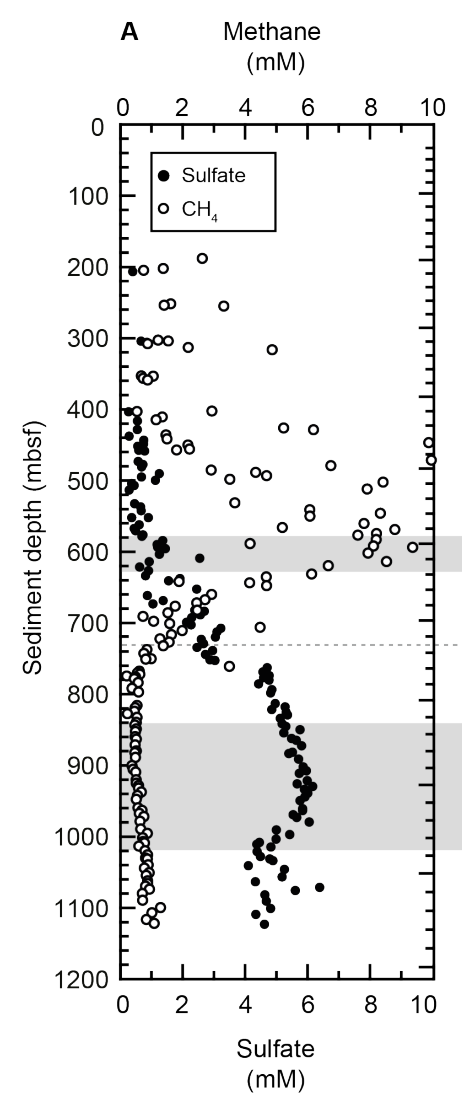

B $\quad \mathrm{C}_{1} / \mathrm{C}_{2}$

C Acetate

D Potential MG rate
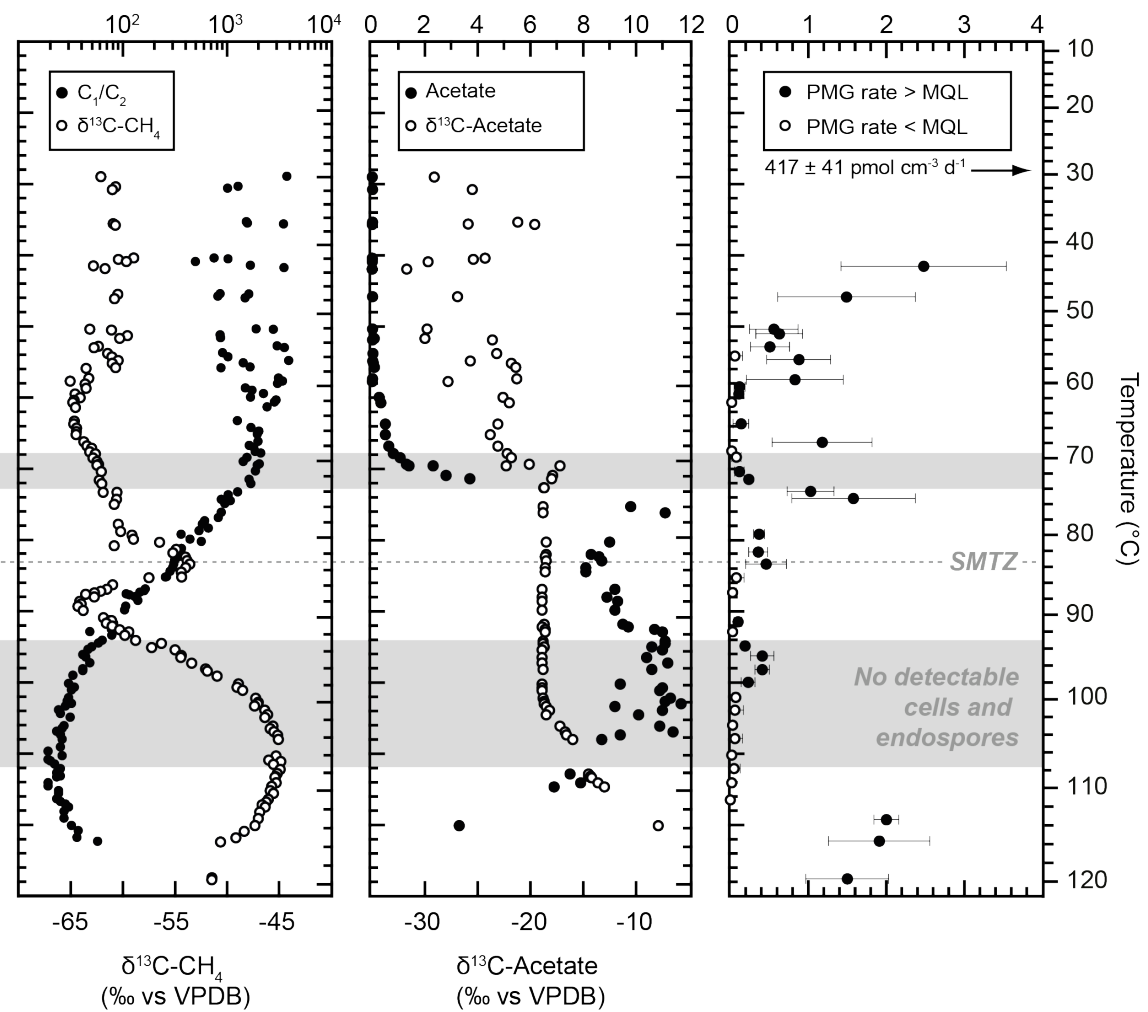

Fig. 2. Geochemical signals of microbial metabolism at Site C0023. (A) Dissolved methane (14) and sulfate (14), (B) $\mathrm{C}_{1} / \mathrm{C}_{2}$ ratios (14) and $\delta^{13} \mathrm{C}_{-}-\mathrm{CH}_{4}$, (C) dissolved acetate and $\delta^{13} \mathrm{C}$-acetate, and (D) potential rates of methanogenesis (MG) based on conversion of ${ }^{14} \mathrm{C}-\mathrm{CO}_{2}$ to ${ }^{14} \mathrm{C}-\mathrm{CH}_{4}$; note that the value at 180 mbsf lies off the scale off the chart. Potential MG (PMG) rates were determined at $40^{\circ} \mathrm{C}$ for $\leq 360 \mathrm{mbsf}$, $60^{\circ} \mathrm{C}$ for $405-585 \mathrm{mbsf}, 80^{\circ} \mathrm{C}$ for $604-775 \mathrm{mbsf}$, and $95^{\circ} \mathrm{C}$ for $\geq 816 \mathrm{mbsf}$. The minimum quantification limit (MQL) was $0.094 \mathrm{pmol} \mathrm{CH}_{4} \mathrm{~cm}^{-3} \mathrm{~d}^{-1}$. Gray shading, SMTZ and temperature axis are as in Fig. 1. VPDB in panels $B$ and $D$ is the Vienna Pee Dee Belemnite standard. 


\section{Supplementary Materials for}

\section{Temperature limits to deep subseafloor life in the Nankai Trough subduction zone}

V. B. Heuer, ${ }^{1 *}$ F. Inagaki, ${ }^{2,3 *}$ Y. Morono, ${ }^{3 *}$ Y. Kubo, ${ }^{4, a}$ A. J. Spivack, ${ }^{5}$ B. Viehweger, ${ }^{1}$ T. Treude, ${ }^{6}$ F. Beulig, ${ }^{7, b}$ F. Schubotz, ${ }^{1}$ S. Tonai, ${ }^{8}$ S. A. Bowden, ${ }^{9}$ M. Cramm, ${ }^{10}$ S. Henkel, ${ }^{11}$ T. Hirose, ${ }^{3}$ K. Homola, ${ }^{5}$ T. Hoshino, ${ }^{3}$ A. Ijiri, ${ }^{3}$ H. Imachi, ${ }^{12}$ N. Kamiya, ${ }^{13, \mathrm{c}}$ M. Kaneko, ${ }^{14}$ L. Lagostina, ${ }^{15, \mathrm{~d}}$ H. Manners, ${ }^{16}$ H.-L. McClelland, ${ }^{17, \mathrm{e}} \mathrm{K}$. Metcalfe, ${ }^{18}$ N. Okutsu, ${ }^{19, f}$ D. Pan, ${ }^{20,8}$ M. J. Raudsepp, ${ }^{21, h}$ J. Sauvage, ${ }^{5, i}$ M.-Y. Tsang, ${ }^{22}$ D. T. Wang, ${ }^{23, j}$ E. Whitaker, ${ }^{24}$ Y. Yamamoto, ${ }^{25, k}$ K. Yang, ${ }^{26,1}$ L. Maeda, ${ }^{4}$ R. R. Adhikari, ${ }^{1}$ C. Glombitza, ${ }^{27}$ Y. Hamada, ${ }^{3}$ J. Kallmeyer, ${ }^{28}$ J. Wendt, ${ }^{1}$ L. Wörmer, ${ }^{1}$ Y. Yamada, ${ }^{2}$ M. Kinoshita, ${ }^{29}$ K.-U. Hinrichs ${ }^{1 \S}$

*V.B.H, F.I., and Y.M. contributed equally to this work.

${ }^{\S}$ Corresponding author: E-mail: khinrichs@uni-bremen.de (K.-U.H.)

${ }^{1}$ Center for Marine Environmental Sciences (MARUM), University of Bremen, Bremen, Germany

${ }^{2}$ Research and Development Center for Ocean Drilling Science (ODS), Japan Agency for Marine-Earth Science and Technology, Yokohama, Japan

${ }^{3}$ Kochi Institute for Core Sample Research (KCC), Japan Agency for Marine-Earth Science and Technology, Kochi, Japan

${ }^{4}$ Center for Deep Earth Exploration (CDEX), Japan Agency for Marine-Earth Science and Technology, Yokohama, Japan

${ }^{5}$ Graduate School of Oceanography, University of Rhode Island, Narragansett, USA

${ }^{6}$ Department of Earth, Planetary, and Space Sciences, Department of Atmospheric and Oceanic Sciences, University of California, Los Angeles (UCLA), Los Angeles, USA

${ }^{7}$ Center for Geomicrobiology, Department of Bioscience, Aarhus University, Aarhus, Denmark ${ }^{8}$ Faculty of Science and Technology, Kochi University, Kochi, Japan

${ }^{9}$ Department of Geology and Petroleum Geology, School of Geosciences, University of Aberdeen, Aberdeen, United Kingdom

${ }^{10}$ Department of Biological Sciences, University of Calgary, Calgary, Canada

${ }^{11}$ Alfred Wegener Institute, Helmholtz Centre for Polar and Marine Research, Bremerhaven, Germany

${ }^{12}$ Institute for Extra-cutting-edge Science and Technology Avantgarde Research, Japan Agency for Marine-Earth Science and Technology, Yokosuka, Japan

${ }^{13}$ Graduate School of Integrated Basic Sciences, Nihon University, Tokyo, Japan

${ }^{14}$ Geomicrobiology Research Group, National Institute of Advanced Industrial Science and Technology (AIST), Tsukuba, Japan

${ }^{15}$ Department of Environmental Systems Science, ETH Zürich, Zürich, Switzerland

${ }^{16}$ School of Geography, Earth and Environmental Sciences, Faculty of Science and Engineering, Plymouth University, Plymouth, United Kingdom

${ }^{17}$ Department of Earth and Planetary Sciences, Washington University in St. Louis, St. Louis, USA

${ }^{18}$ Division of Geological and Planetary Sciences, California Institute of Technology, Pasadena, USA 
${ }^{19} \mathrm{Atmosphere}$ and Ocean Research Institute, University of Tokyo, Tokyo, Japan

${ }^{20}$ Department of Subsurface Geobiological Analysis and Research, Japan Agency for Marine-Earth Science and Technology, Yokosuka, Japan

${ }^{21}$ School of Earth Sciences, University of Queensland, St. Lucia, Australia

${ }^{22}$ Department of Earth Sciences, University of Toronto, Toronto, Canada

${ }^{23}$ Department of Earth, Atmospheric and Planetary Sciences, Massachusetts Institute of Technology, Cambridge, USA

${ }^{24}$ Department of Oceanography, Texas A\&M University, College Station, USA

${ }^{25}$ Department of Mathematical Science and Advanced, Technology (MAT), Japan Agency for Marine-Earth Science and Technology, Yokosuka, Japan

${ }^{26}$ Department of Earth System Sciences, Yonsei University, Seoul, Republic of Korea

${ }^{27}$ Institute of Biogeochemistry and Pollutant Dynamics, ETH Zürich, Zürich, Switzerland

${ }^{28} \mathrm{Helmholtz}$ Centre Potsdam, GFZ German Research Centre For Geosciences, Potsdam, Germany

${ }^{29}$ Earthquake Research Institute, University of Tokyo, Tokyo, Japan

Present address:

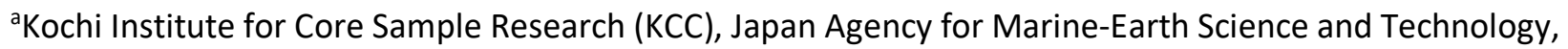
Kochi, Japan

${ }^{b}$ Department of Ecological Microbiology, University of Bayreuth, Bayreuth, Germany

${ }^{\circ}$ Graduate School of Engineering, Kyoto University, Kyoto, Japan

dRobert Koch-Institut, Berlin, Germany

eSchool of Earth Sciences, University of Melbourne, Melbourne, Australia

fInstitute for Marine-Earth Exploration \& Engineering, Japan Agency for Marine-Earth Science and Technology, Yokohama, Japan

gDepartment of Ecology \& Environmental Studies, The Water School, Florida Gulf Coast University, Fort Myers, USA

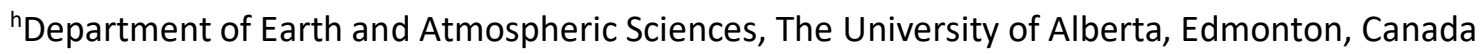

'Department of Marine Sciences, University of Gothenburg, Gothenburg, Sweden

'ExxonMobil, 22777 Springwoods Village Parkway, Spring, Texas 77389 USA

kGraduate School of Geoscience, Kobe University, Kobe, Japan

'Department of Oceanography, Pusan National University, Busan, Republic of Korea

This pdf file includes

Supporting information, incl. Material and Methods and supporting text

Figures S1 to S10

Tables S1 to S2

References 35-81 
This study aimed to elucidate the influence of temperature on microbial communities in deep subseafloor sediments, and to determine the limits of microbial life. The particular challenge of such an endeavor arises from the necessity to potentially demonstrate the absence of microbial life. Accordingly, the highest possible levels of analytical sensitivity and contamination control need to be achieved under the demanding conditions of kilometer-deep scientific drilling. Expedition 370 of the International Ocean Discovery Program (IODP) was designed to meet this challenge. Our study site is located at the deformation front of the Nankai Trough subduction zone (fig. S1), $125 \mathrm{~km}$ off Cape Muroto, Japan, in the vicinity of Sites 808 and 1174 of the Ocean Drilling Program (ODP) $(35,13)$. Due to high heat flow in this region (36), we expected to encounter the currently known upper temperature record of microbial life in the laboratory, $\sim 120^{\circ} \mathrm{C}(5)$, at a relatively shallow depth of $\sim 1.2 \mathrm{~km}$ below seafloor. From such depth, sediment cores can be retrieved by non-riser drilling, i.e. without the continuous circulation of dense drilling muds in a riser system, which is needed to advance to depths of several kilometers but associated with considerable contamination risks (3). At the same time, the increase of temperature with depth is still gradual enough to allow the observation of critical transitions with high depth and temperature resolution. For example, a $10^{\circ} \mathrm{C}$ change across the upper temperature limits of mesophiles $\left(\sim 43^{\circ} \mathrm{C}\right)$, thermophiles $\left(\sim 80^{\circ} \mathrm{C}\right)$, or deep subseafloor life in general can be expected to stretch over a 100 $\mathrm{m}$ depth interval in the borehole.

When Site $\mathrm{C} 0023$ (Hole C0023A: 32 $22.00^{\prime} \mathrm{N}, 134^{\circ} 57.98^{\prime} \mathrm{E}, 4776 \mathrm{~m}$ water depth) was drilled and cored with DV Chikyu to a total depth of 1180 meters below seafloor (mbsf), sediment coring was combined with in-situ temperature measurements down to $408 \mathrm{mbsf}$. For greater depths, a precise temperature model was established based on detailed physical property measurements. Operations were concluded with the installation of a borehole observatory for long-term temperature measurements down to 860 mbsf. No cores were retrieved from $<189 \mathrm{mbsf}$, as the upper portion of the hole needed to be stabilized with a 20-inch casing. Cores of typically 3-9 m length were cut by a short advance modified hydraulic piston coring system (S-HPCS) from $189 \mathrm{mbsf}$ to $408 \mathrm{mbsf}$, and by continuous rotary core barrel (RCB) coring from $>410 \mathrm{mbsf}$ to the bottom of the hole. Several measures were taken to minimize potential contamination and alteration of samples. (I) To avoid intrusion of microbes from drilling fluid during coring, intact parts of sediment cores without drilling induced fractures were identified by X-ray computed tomography (CT) image scans, sampled in the form of whole round cores (WRC) and cleaned immediately after retrieval. (II) To avoid introduction of microbes with airborne particles during sample processing in the laboratory, a super-clean working environment was established using tabletop air filtration units and static electricity neutralizers (ionizers) inside anaerobic chambers and clean benches. (III) To minimize alteration of depressurized samples and loss of information during storage, the carefully cleaned, anaerobically packed, refrigerated or frozen samples were transported by helicopter shuttle to Kochi Core Center (KCC) in Kochi Prefecture, Japan, on an almost daily basis. On shore, samples were further processed without delay in a laboratory that meets the International Organization for Standardization (ISO) Class 1 clean room standards. Operations at Site C0023 started with IODP Expedition 370 in September 2016 and finished with the retrieval of data from the temperature observatory and collection of surface sediments during RV Kairei/ROV Kaiko cruise KR18-04 in March 2018. All operations, quality control measures, sampling procedures, shipboard analyses, and the installation and retrieval of the borehole observatory are described in detail in the expedition reports $(14,37)$. 
As part of the Philippine Sea Plate, Site $\mathrm{C0023}$ has been approaching the trench from the Shikoku Basin at a rate of around 41-65 $\mathrm{mm} \mathrm{y}^{-1}$ for a total of $\sim 16$ million years (My). During the $\sim 750 \mathrm{~km}$ long passage from spreading center to subduction zone, a $14 \mathrm{~m}$ thick layer of volcaniclastics and a $618 \mathrm{~m}$ thick layer of hemipelagic mudstone, occasionally interspersed by volcanic ash layers, piled up on the crust with an average sedimentation rate of $\sim 35-53 \mathrm{~m} \mathrm{My}^{-1}$ (38). Upon arrival in the trench $\sim 0.4$ million years ago (Ma), sedimentation rates increased drastically to up to $1319 \mathrm{~m} \mathrm{My}^{-1}$ (38). Since then, a $494 \mathrm{~m}$ thick layer of sand and silt rich mudstone accumulated, partly from debris flows or turbidity currents. The resulting succession of lithological units (fig. S2A) is consistent with previous findings $(13,35)$ and comprises axial trench-wedge facies (Subunit IIA, 189-318.5 mbsf), outer trench-wedge facies (Subunit IIB, 353-428 mbsf), trench-to-basin transitional facies (Subunit IIC, 428-494 mbsf), upper Shikoku Basin facies (Unit III, 494-637.25 mbsf), lower Shikoku Basin facies (Unit IV, 637.25-1112 mbsf), acidic volcaniclastics (Unit V, 1112-1125.9 mbsf), and basaltic basement (Unit VI, 1125.9-1177 mbsf) (14). Both basin and trench deposits contain only little organic matter. Total organic carbon (TOC) contents decrease monotonically from $0.5 \mathrm{wt} \%$ at $190 \mathrm{mbsf}$ to $0.02 \mathrm{wt} \%$ at the bottom of the hole, and low TOC/N ratios around $5.8 \pm 2.1$ point to a predominantly marine source of the organic material (cf. Fig. F51 in ref. 14).

Site $\mathrm{C0023}$ is located in the protothrust zone of the Nankai Accretionary prism, which has formed by the off-scraping of sediment from the descending Philippine Plate (39). Situated seaward from the frontal thrust, Site $\mathrm{C0023}$ shows little deformation compared to the landward part of the prism, but detachment surfaces are present and bisect the succession of lithological units into three separate domains (fig. S2A), i.e., (I) an upper domain that comprises the prism, cut by low angle thrusts, (II) the décollement zone at 758-796 mbsf, consisting of relatively thin, characteristically brecciated fault zones that are alternating with several meter thick intact zones, and (III) an underthrust domain with extensional faulting and no thrust fault zones (14).

The physical properties of Site C0023 are reflected in the down-hole profiles of porosity, $P$-wave velocity, and equivalent strength (EST) (fig. S2, ref. 14, 33). All three parameters show distinct deviations from a smooth compaction curve. (I) Porosities, inferred from moisture and density measurements of discrete sediment and rock samples (fig. S2B), generally decrease with increasing depth from $40 \%$ to $50 \%$ at 200 mbsf to $32 \%$ at 1030 mbsf. However, a distinct reversal of this trend occurs across and below the décollement, where porosities increase by 5-7\% (760-830 mbsf). In contrast, porosities decrease more sharply than expected in mud rocks and volcaniclastics at the bottom of the hole ( $>1030 \mathrm{mbsf}$ ). In the underlying basaltic basement rocks, porosities range from $5.5 \%$ to $25 \%$. (II) $P$-wave velocity stands for the speed at which ultrasonic sound waves pass through a material, and it is related not only to the material's porosity but also to its compressibility and shear strength. At Site C0023, $P$-wave velocities, measured on intact sediment cores, reflect the general down-hole decrease of porosity as well as its excursion towards higher porosities across the décollement and the sharp decrease of porosities in sediments and basaltic rocks at the bottom of the hole (fig. S2C). At $\sim 630 \mathrm{mbsf}$, however, elevated $P$ wave velocities do not match the high porosities of bulk sediment samples (45-50\%). This finding points to a stiffening of the fine to coarse tuff and tuffaceous muds in this interval, potentially due to diagenetic mineral alteration reactions (40). (III) EST is a measure for the in-situ strength of the geological formation, i.e. its relative triaxial shear strength that can be deduced from parameters recorded during the drilling operation, such as weight-on-bit, top drive torque, and rotations per minute (33). The down- 
hole EST profile of Site C0023 (fig. S2D, ref. 33) shows distinctly elevated mechanical strength for the tuff-rich sediments around $\sim 630 \mathrm{mbsf}$, as well as the presence of a mechanically weak zone below the décollement, stretching from $\sim 800-1050$ mbsf. In this zone, EST decreases by a factor of 5 from 10 to 2 MPa. While the mechanical weakening is clearly evident in the EST profiles, which has been measured under in-situ pressure conditions, there is no corresponding decrease in the down-hole $P$-wave velocity profile, which has been generated on core samples after pore pressure had been released during recovery. The deviation between EST and $P$-wave velocity suggests that the mechanical weakness of the upper portion of the underthrust domain is related to high in-situ pore pressure. If pore pressure exceeds hydrostatic pressure, the effective pressure on sediments is reduced and consequently their insitu strength decreases. Together, the physical properties of Site C0023 suggest that (a) volcaniclastic sediments in the prism domain form a distinct, mechanically strong layer $630 \mathrm{mbsf}$, (b) the upper $250 \mathrm{~m}$ of the underthrust domain ( $800-1050 \mathrm{mbsf}$ ) are under-compacted and mechanically weak due to the presence of overpressurized fluids, and (c) the décollement (758-796 mbsf) forms a barrier that does not allow fluids to flow from the underthrust sediments into the prism domain.

These observations agree well with previous studies, which infer the presence of high-fluid pressure below the décollement from seismic imaging $(41,42)$, suggest the possibility that a décollement acts as a barrier inhibiting upward fluid convection, leading to high pore pressure and increased structural weakness of subducting sediments (43-45), and explain the surplus of water below the décollement with in-situ dehydration of clay minerals $(46,47)$ and/or channelized lateral advective fluid flow from deeper portions $(48,49)$.

At Site C0023, signs of low-temperature hydrothermal mineralization provide evidence for fluid flow in the underthrust domain $(14,15)$. Between 775 and $1121 \mathrm{mbsf}$, hydrothermal mineralization assemblages occur in the form of veins and stratabound alteration patches, which are rich in barite and rhodochrosite, pale-yellow in color, and often 10-15 cm thick (14). Due to their elevated density, hydrothermal minerals are visible in X-ray CT images, and consequently their down-hole distribution can be tracked by radiodensity logging, as shown in fig. S2E (cf. ref. 50). For the known hydrostatic pressures and modern concentrations of dissolved barium within the underthrust sediments of Site C0023, retrograde solubility for barite would occur above $145^{\circ} \mathrm{C}(15)$. Analyses of fluid inclusions in authigenic barite minerals revealed high salinities of around $16-25 \% \mathrm{NaCl}$ equivalent and trapping temperatures ranging from $118-141^{\circ} \mathrm{C}$ at $822 \mathrm{mbsf}$ to $146-219^{\circ} \mathrm{C}$ at $1010 \mathrm{mbsf}(15)$. These salinities and

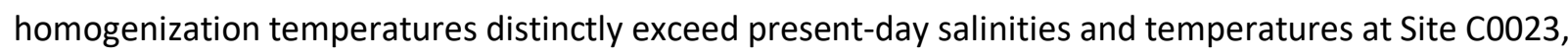
and point to mixing with deep-sourced hot and saline fluids (15). The morphology of the authigenic minerals in veins and burrows suggest that the ingression of such fluids started before and continued throughout the deformation of underthrust sediments (15). Tsang et al. (15) estimate the duration of individual hydrothermal fluid flow events by fitting a heat flow model, which predicts the spatial and temporal expansion of thermal aureoles along permeable sedimentary fabrics, to the actual size of hydrothermal veins and alteration patches observed by visual core description and radiodensity logging $(14,50)$. They conclude that the ingression of hydrothermal fluids has occurred in the form of episodic short-term pulses, which have lasted for less than three days and altered sediment temperatures within up to $30 \mathrm{~cm}$ thick aureols around veins or alteration patches (15). Hydrothermal mineral assemblages were found down to $1121 \mathrm{mbsf}(14,15)$. Their absence at greater depths points to a lack of hydrothermal influence in the oldest sediments of Site C0023. Instead, hematized sediments and reddening occur in both sediments and basalts at the sediment/basalt interface together with lowtemperature mineral assemblages such as calcite veins that penetrate both crust and sediment $(14,15)$. 
The close spatial association is typical for umbers, i.e. ferruginous horizons adjacent to oceanic basement that are associated with the end of rifting and low-temperature off-axis activity (15).

The episodic ingression of hydrothermal fluids has no measurable effect with respect to petroleum generation (15). Instead, the current thermal maturity of sedimentary organic matter at Site $\mathrm{C} 0023$ can solely be explained by conventional burial diagenesis (15). Three thermal maturity parameters, which were calculated from hopane and sterane biomarkers, indicate a thermal regime in which catagenesis has just begun, but the thermal state of Site $\mathrm{C0023}$ can only be explained if past heat flows were higher than today (15). Biomarker and present-day temperature data agree best with a basin modeling scenario, in which heat flow was distinctly elevated $2 \mathrm{Ma}$, and formations in underthrust sediments began to cool about $0.1 \mathrm{Ma}(15)$. Against the tectonic background of southeast Japan, a conceivable scenario for Site $\mathrm{C} 0023$ includes high heat flow close to the spreading center until $15 \mathrm{Ma}$, a subsequent transition through lower off-axis heat flows, and a brief increase in past heat flow around 2 Ma due to the far-field effect of increased volcanic activity (15). This scenario is consistent with a previous thermal history model for adjacent ODP Site 1174 (12).

Sediment temperature is a function of heat flow, thermal conductivity and depth below seafloor. Consequently, the arrival of Site $\mathrm{C0023}$ in the trench $\sim 0.4 \mathrm{Ma}$ and the associated $\sim 30$-fold increase in sedimentation rates (38) led to a rapid $\sim 50^{\circ} \mathrm{C}$ increase of temperature across the entire sediment column.

\section{Modern temperature regime of Site C0023 (fig. S3-S4)}

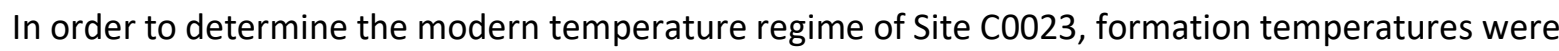
measured in situ from 189.3 to 407.6 mbsf during drilling (14). Based on the deduced heat flow and thermal conductivities measured on samples, a temperature profile to the bottom of Hole C0023A was synthesized with the assumption of purely vertical conductive and steady-state heat flow (fig. S3). The projected downhole temperature reaches $\sim 86^{\circ} \mathrm{C}$ at the top of the décollement zone and $119.7 \pm 3.4^{\circ} \mathrm{C}$ at the bottom of the hole (fig. S4). Post-cruise monitoring of temperatures in the borehole observatory confirm the projected temperatures and thus verify our temperature model (37).

\subsection{Overview of Method}

We calculated the in-situ temperature profile based on the step-wise integration of Fourier's Law,

$$
q=-\kappa(z) \frac{d T(z)}{d z}
$$

which gives,

$$
\mathrm{T}(\mathrm{z})=\mathrm{T}\left(\mathrm{z}_{\mathrm{o}}\right)-\mathrm{q} \sum_{\mathrm{i}=0}^{\mathrm{N}}\left(\frac{\Delta \mathrm{z}_{\mathrm{i}}}{\kappa(\mathrm{z})_{\mathrm{i}}}\right)
$$

where,

$T(z)=$ temperature,

$Z=$ depth from the sediment-bottom water interface,

$\kappa(z)=$ thermal conductivity,

$\Delta \mathrm{z}_{\mathrm{i}}=$ difference in depth between successive measurements of $\kappa(z)$

$T\left(z_{0}\right)=$ temperature at the depth of first measurement, $z_{0}$, 
$q=$ heat flow, (note that in this coordinate system $q<0$ )

$171 \sum_{i=0}^{N}\left(\frac{\Delta z_{i}}{k(z)_{i}}\right)=$ thermal resistance, and

$172 N=$ number of thermal conductivity measurements (51).

173 Application of equation 2 requires an estimate of the heat flow and a profile of thermal conductivities. Its use also assumes that heat flow is conductive, and is constant with depth as well as time. We measured thermal conductivities with high spatial resolution, nearly one measurement per core down to the basement $(N=111)(14)$. The assumption of constant heat flow with depth may not be correct, however. When the sediment accumulation rate is high and the column length is long, as potentially is the case in the Nankai Trough, conduction may not keep pace with the burial of cold sediment and heat flow can vary with depth.

To test the assumption of steady-state heat flow with depth and time at Site C0023, we first solve the time-dependent heat flow equation, taking $\kappa, \rho$, and $C_{p}$ as depth independent

$$
\frac{\partial \mathrm{T}(\mathrm{z}, \mathrm{t})}{\partial \mathrm{t}}=\frac{\mathrm{k}}{\rho \mathrm{C}_{\mathrm{p}}} \frac{\partial^{2} \mathrm{~T}(\mathrm{z}, \mathrm{t})}{\partial \mathrm{z}^{2}}
$$

where

$185 \mathrm{C}_{\mathrm{p}}=$ bulk sediment specific heat.

186

The solution of equation 3 for a sediment column whose length continuously increases due to sediment accumulation and with constant basement heat flow is,

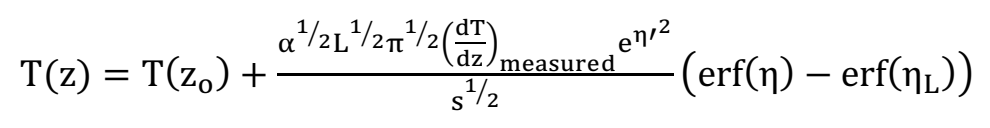

where we used the Buckingham $\pi$ theorem (52) to define the non-dimensional variable, $\eta$,

$$
\eta=\frac{(\mathrm{L}-\mathrm{z}) \mathrm{s}^{1 / 2}}{2 \alpha^{1 / 2 \mathrm{~L}^{1 / 2}}}
$$

with

$\alpha=$ thermal diffusivity, $\kappa /\left(\rho \mathrm{C}_{\mathrm{p}}\right)$,

$\mathrm{s}=$ linear sediment accumulation rate,

$\mathrm{L}=$ sediment column length, and

$\eta^{\prime}=$ value of $\eta$ at the depth the temperature gradient is measured $\eta_{\mathrm{L}}=$ value of $\eta$ at depth $\mathrm{z}=\mathrm{L}$, the sediment-basement interface.

We then compare the solution of equation 1 (constant heat flux and assuming constant $\kappa$ ) to the time dependent solution, equation 4 , to determine the temperature error offset, $\Delta \mathrm{T}(\mathrm{z}=\mathrm{L})=\mathrm{T}(\mathrm{z}=\mathrm{L})_{\text {steady- }}$ state $-\mathrm{T}(\mathrm{z}=\mathrm{L})$ time-dependent, that results from assuming steady-state heat flow. At the bottom of the sediment column, the temperature offset, $\Delta \mathrm{T}(\mathrm{z}=\mathrm{L})$, of these two solutions is approximately given by:

$$
\Delta \mathrm{T}(\mathrm{z}=\mathrm{L}) \approx \frac{-\left(\frac{\mathrm{dT}}{\mathrm{dz}}\right)_{\text {measured }} \mathrm{e}^{\mathrm{n}^{2} \mathrm{~L}^{2} \mathrm{~s}}}{12 \alpha}
$$



subtracted the steady-state solution, equation 3.

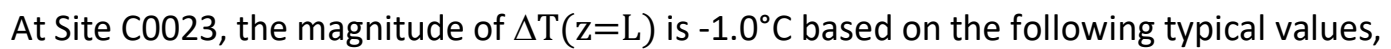

$(\mathrm{dT} / \mathrm{dz})_{\text {measured }}=0.1\left({ }^{\circ} \mathrm{C} \mathrm{m}^{-1}\right)$,

L-z for depth of temperature gradient measurement $=950$ ( $\mathrm{mbsf})$,

$\mathrm{L}=1176(\mathrm{~m})$, $\mathrm{s}=3.810^{-11}\left(\mathrm{~m} \mathrm{~s}^{-1}\right)$,

$\rho=2.010^{3}\left(\mathrm{~kg} \mathrm{~m}^{-3}\right)$ and

$\mathrm{C}_{\mathrm{p}}=1.410^{3}\left(\mathrm{~J} \mathrm{~kg}^{-1}{ }^{\circ} \mathrm{C}^{-1}\right)$.

This is an upper limit of the offset as the sediment accumulation rate was more than an order of magnitude lower than assumed here during the accumulation of about half of the sediment column. This offset is within the error of measurement uncertainty $\left(3.4^{\circ} \mathrm{C}\right.$, see below), justifying the conductive steady-state assumption.

\subsection{Measurements at Site $\mathrm{COO23}$}

Details of the methods for measuring temperature and thermal conductivity are given in refs. 14 and 53.

Briefly, temperature was measured in-situ using a short advance modified hydraulic piston coring system (S-HPCS) equipped with an advanced piston corer temperature tool (APCT-3) until the S-HPCS could no longer penetrate properly into the formation (14). The APCT-3 consists of a thermistor that is hydraulically stroked up to $4.5 \mathrm{~m}$ into the sediment, well beyond the thermal influence of drilling operations. After penetration, it takes $\sim 10 \mathrm{~min}$ for the sensor to equilibrate to the in-situ temperature of the formation. Measured temperatures were extrapolated from the APCT-3 measurements, using the program TP-Fit (53). The uncertainty of individual measurements is estimated to be $0.1-0.2^{\circ} \mathrm{C}$ (e.g., ref. 54).

Thermal conductivity was measured on sediment and rock samples using either the full-space needle probe or the half-space line source depending on sediment strength; the methods are described in detail in the expedition report (14). Values of thermal conductivity are based on the observed rise in temperature for a given quantity of heat. The full-space needle and the half-space line probes were calibrated at least once every $24 \mathrm{~h}$. The calibration was performed on Macor samples of known thermal conductivity $\left(1.611 \pm 2 \% \mathrm{~W} \mathrm{~m}^{-1} \mathrm{~K}^{-1}\right.$ and $1.652 \pm 2 \% \mathrm{~W} \mathrm{~m}^{-1} \mathrm{~K}^{-1}$ for the full- and half-space probes, respectively). We base the uncertainty of the entire method, $\sim 2 \%$, on the variance of the measured data from a smooth fit.

Eight formation temperatures were measured in-situ between 189.3 to $407.6 \mathrm{mbsf}$. Based on quality assessment of coring and time series temperature data while measuring, we used four temperature data among the eight to determine the thermal gradient and heat flow. Temperatures increased linearly as a function of thermal resistance, $\sum_{\mathrm{i}=0}^{\mathrm{N}}\left(\frac{\Delta \mathrm{z}_{\mathrm{i}}}{\mathrm{k}(\mathrm{z})_{\mathrm{i}}}\right)$ between 204.1 and $355.2 \mathrm{mbsf}$ (fig. S3). In the temperature calculations, the value of $\kappa(\mathrm{z})_{\mathrm{i}}$ is taken as the average of the two values measured at adjacent depths. The calculated heat flow, based on a linear least square of temperature vs. thermal resistance is -0.140

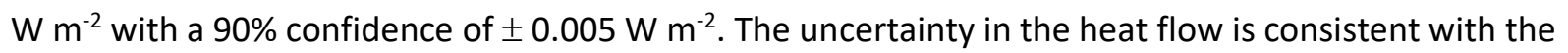
expected uncertainties in individual temperature measurements of $\sim 0.1$ to $0.2^{\circ} \mathrm{C}$. 
Estimated temperatures are shown in fig. S4. The estimated temperature at the bottom of Hole C0023A

242 (1176.6 mbsf) is $119.7 \pm 3.4^{\circ} \mathrm{C}$ (90\% confidence limit).

The confidence limit is based on propagating the errors associated with the heat flow and thermal resistance. The uncertainty in the calculated temperature is dominated by the uncertainty in the heat flow ( $>90 \%$ of the uncertainty). Uncertainty in thermal conductivity is minor due to the large number of measurements.

\section{Cell concentrations (Fig. 1A)}

Enumeration of microbial cells in subseafloor environments that are situated close to the limits of habitability requires the highest possible levels of analytical sensitivity and contamination control (55). In order to improve the detection limit of cell enumeration, microbial cells were detached from the sediment matrix by ultrasonication, subsequently recovered by density gradient centrifugation and concentrated on polycarbonate membrane filters, before they were treated with the nucleic acid stain SYBR Green I, and manually counted under the microscope. For maximal contamination control, we implemented rigorous quality assurance ( $Q A$ ) and quality control $(\mathrm{QC})$ measures for all steps involved in core recovery, core processing, and sample analysis. Numerous cell counts in the range of the procedural blank (fig. S6) and negligible drilling disturbance (fig. S7) testify to the effectiveness of contamination control during sample handling. Detailed information on analytical methods and QA/QC procedures and results are given in the expedition report (14).

\subsection{Cell enumeration}

In principle, sediment samples for cell enumeration were taken from the very center of selected, quality controlled WRCs under anoxic and sterile conditions, using sterilized spatulas or cut-off syringes in unconsolidated sediments and a table-top mini-drill in consolidated sediments. In consolidated sediments, the sterilized drill bit of the mini-drill was exchanged after each sample. Soft sediments were immediately submerged in fixation solution. Consolidated sediments were kept under anoxic conditions until they were crushed by ceramic pestle and mortar and immersed in fixation solution. Approximately $10 \mathrm{~cm}^{3}$ of powdered sediment were thoroughly mixed with fixation solution consisting of $20 \mathrm{~mL}$ of $3 \%$ $(\mathrm{w} / \mathrm{v})$ sodium chloride and $10 \%(\mathrm{v} / \mathrm{v})$ neutralized formalin (containing $3.8 \%$ formaldehyde). If necessary, the mixture was stored at $4^{\circ} \mathrm{C}$.

Fixed cells were separated from the slurry via ultrasonication and density gradient centrifugation (56). For cell detachment, a $1 \mathrm{~mL}$ aliquot of the formalin-fixed sediment slurry was amended with $1.4 \mathrm{~mL}$ of $2.5 \% \mathrm{NaCl}, 300 \mu \mathrm{L}$ of pure methanol, and $300 \mu \mathrm{L}$ of detergent mix (ref. $57,100 \mathrm{mM}$ ethylenediamine tetraacetic acid [EDTA], $100 \mathrm{mM}$ sodium pyrophosphate, 1\% [v/v] Tween-80). The mixture was thoroughly shaken for $60 \mathrm{~min}$ (Shake Master, Bio Medical Science, Japan), and subsequently sonicated at $160 \mathrm{~W}$ for $30 \mathrm{~s}$ for 10 cycles (Bioruptor UCD-250HSA; Cosmo Bio, Japan). The detached cells were recovered by centrifugation based on the density difference of microbial cells and sediment particles, which allows collection of microbial cells in a low-density layer. To this end, the sample was transferred onto a set of four density layers composed of $30 \%$ Nycodenz $\left(1.15 \mathrm{~g} \mathrm{~cm}^{-3}\right), 50 \%$ Nycodenz $\left(1.25 \mathrm{~g} \mathrm{~cm}^{-3}\right)$, $80 \%$ Nycodenz $\left(1.42 \mathrm{~g} \mathrm{~cm}^{-3}\right)$, and $67 \%$ sodium polytungstate $\left(2.08 \mathrm{~g} \mathrm{~cm}^{-3}\right)$. Cells and sediment particles were separated by centrifugation at $10,000 \times \mathrm{g}$ for $1 \mathrm{~h}$ at $25^{\circ} \mathrm{C}$. The light density layer was collected using a $20 \mathrm{G}$ needle syringe. The heavy fraction, including precipitated sediment particles, was resuspended with $5 \mathrm{~mL}$ of $2.5 \% \mathrm{NaCl}$, and centrifuged at $5000 \times \mathrm{g}$ for $15 \mathrm{~min}$ at $25^{\circ} \mathrm{C}$. The supernatant was combined 
with the previously recovered light density fraction. With the remaining sediment pellet, the density separation was repeated. The sediment was resuspended using $2.1 \mathrm{~mL}$ of $2.5 \% \mathrm{NaCl}, 300 \mu \mathrm{L}$ of methanol, and $300 \mu \mathrm{L}$ of detergent mix and shaken at $500 \mathrm{rpm}$ for $60 \mathrm{~min}$ at $25^{\circ} \mathrm{C}$, before the slurry sample was transferred into a fresh centrifugation tube where it was layered onto another density gradient and separated by centrifugation just as before. The light density layer was collected using a 20G needle syringe, and combined with the previously collected light density fraction and supernatant to form a single suspension for cell counting.

For cell enumeration, a 50\%-aliquot of the collected cell suspension was passed through a $0.22-\mu \mathrm{m}$ polycarbonate membrane filter. Cells on the membrane filter were treated with SYBR Green I nucleic acid staining solution (1/40 of the stock concentration of SYBR Green I diluted in Tris-EDTA [TE] buffer). The number of SYBR Green I-stained cells were enumerated by direct microscopic count $(4,58)$. At least 900 fields of view were analyzed for each whole membrane filter.

The cell staining with DNA-staining dye, including SYBR Green I, critically relies on the penetration of dye into the cells. For normal "cells", including subseafloor microbes, the staining has worked reliably and contributed to the exploration of the deep subseafloor biosphere (3). However, we found that the situation is different in endospores as they do not allow DNA-dyes to penetrate inside and are resistant to DNA-staining. The example in fig. $\mathrm{S} 5$ shows the staining of vegetative cells (fig. S5a) and endospores (fig. S5b) of Bacillus subtilis NBRC13719. Although the stainability was $100 \%$ in vegetative cells, $98.8 \%$ $(\mathrm{N}=4707)$ spores appeared in orange color in fluorescence observation, which indicated the adsorption and overaccumulation of SYBR Green I on the surface of endospores (58). The adsorption was also indicated by the enlarged image of the orange-stained endospores, in which the center of the endospore remained black (i.e. unstained), while the center of the green-stained endospore was well-stained (fig. S5a). In addition, the staining and observation of endospores mixed with sterilized sediment demonstrated the extreme difficulty in identifying spores even for the cultivated species (fig. S5c). These results are consistent with the previous findings according to which endospore abundance assessed by the chemical quantification of dipicolinic acid exceeded the abundance of cells detected by DNAstaining-based direct counts in subseafloor sediments $(18,59)$. Moreover, the stainability of endospores inhabiting the subseafloor environment is expected to be substantially lower than that of cultivated spores of $B$. subtilis (1.2\%). Therefore, we operationally call the SYBR-stainable cells as "vegetative cells" in this study.

\subsection{Quality assurance and quality control ( $Q A / Q C)$}

QA/QC measures were designed to account for three major sources of contamination during sample recovery and processing, namely introduction of microbial cells from drilling fluid, from airborne particles, and from reagents and tools used during sample processing.

Intrusion of seawater and drilling mud during core cutting and recovery - To minimize the risk of drillinginduced contamination, samples for microbiological investigations were taken as intact WRCs from the pristine, undisturbed parts of the recovered cores. Generally, the upper section of a core was not sampled to avoid cross contamination from loose borehole materials accumulating on the bottom of the hole. Undisturbed core intervals were identified based on visual inspection and X-ray CT imaging, which reveals the structural integrity of sediment cores on a sub-millimeter scale. All surfaces of WRCs, which had potentially been in contact with drilling fluid, were removed immediately after core retrieval onboard DV Chikyu to prevent diffusion of potential contaminants from seawater and drilling fluid into the inner part of the core during storage and transport. WRCs were opened in an anaerobic chamber, 
where core liners were removed and all sediment surfaces were scraped off with sterile ceramic knives, before the remaining sediment cores were placed into ESCAL bags and temporarily sealed shut. The bags were removed from the anaerobic chamber, immediately flushed with nitrogen gas to remove $\mathrm{H}_{2}$ gas, vacuum-sealed, and stored at $+4^{\circ} \mathrm{C}$. Afterwards, samples were transferred to shore by helicopter in order to enable prompt processing under clean-room conditions at KCC (see below). On shore, the scraping of WRC surfaces was repeated to further reduce the contamination risk, and samples for cell enumeration $\left(\sim 10 \mathrm{~cm}^{3}\right)$ were taken from the very center of the WRCs.

X-ray CT-imaging not only allows one to identify and to avoid core intervals with fractures prone to contamination, it also enables quantification of core integrity and thus contamination risk for each selected sample (50). Using automated image and data processing routines, pristine, high-quality areas can be distinguished from damaged areas based on the characteristic values and distribution patterns of radiodensity in each $0.625 \mathrm{~mm}$ thick slice image recorded as a DICOM file during X-ray CT scanning. The resulting slice quality $(\mathrm{SQ})$ is a quantitative measure for the relative abundance of drilling induced fractures in a given slice, with a SQ of $100 \%$ indicating the highest possible quality of a slice without any fractures. SQ has been shown to be an effective quality control measure, and automatic identification and removal of slices below a given SQ threshold generates quality-controlled downhole radiodensity profiles closely reflecting geological features (50). A detailed description and evaluation of this new method and its application during Expedition 370 are given in ref. 50.

During Expedition 370, we determined SQ for all $0.625 \mathrm{~mm}$ thick CT slices of the typically $\sim 5-40 \mathrm{~cm}$ long WRC samples selected for cell enumeration, and used the resulting mean slice quality of all CT slices (mean SQ) as a measure for the core quality of an individual cell count sample. This quantitative evaluation shows that careful, X-ray CT guided sample selection achieved the highest possible core quality, i.e. a mean SQ of $100 \%$, in $46 \%$ of all WRCs taken for cell enumeration. The prevalence of excellent core quality in all cell count samples is evident in a typical mean SQ of 99\% (median of 152 samples, fig. S6A).

In addition, established routines for contamination testing were applied to monitor the potential intrusion of drilling fluid into the cores through the use of a chemical tracer (14). In the main pump room of DV Chikyu, the perfluorocarbon (PFC) tracer perfluoromethylcyclohexane was added to the downgoing drilling fluid. After its proper delivery was verified by analysis of drilling fluid captured inside the core liners, the intrusion of PFC into the core was monitored in $\sim 2 \mathrm{~cm}^{3}$ sediment samples taken from the exterior, midway, and interior portions of WRCs. During operations, pumping rates and mixing ratios of drilling mud varied in response to borehole conditions. Consequently, the exact concentration of PFC in the down-going drilling fluid remains unknown. In order to assess the potential drilling induced contamination without this information, we determined PFC recovery. PFC recovery normalizes the PFC concentration measured in the center part of an individual core to the average PFC concentration in the outer parts of all cores $\left(0.22 \pm 0.81 \mu \mathrm{g} \mathrm{cm}^{-3}, \mathrm{~N}=74\right)$, which had been in direct contact with drilling fluid. A $\mathrm{PFC}$ recovery of $0 \%$ in the core center represents the lowest risk of drilling induced contamination. During Expedition 370, PFC recovery was $<1 \%$ in the majority of samples taken from the interior portions of WRCs, and the lack of relation between PFC recovery and vegetative cell abundance suggest that drilling induced contamination is negligible in the high-quality intervals of the sediment cores, which were selected for microbiological samples (fig. S6B).

Contamination of sediment samples from airborne particles during laboratory work - In order to avoid introduction of airborne particles, all sample processing was conducted under clean-room conditions. 
Cleaning and subsampling of WRCs, both onboard DV Chikyu and at KCC, were conducted inside anaerobic chambers (95:5 [v/v] N2: $\mathrm{H}_{2}$ atmosphere; COY Laboratory Products, USA) equipped with a KOACH T 500-F tabletop air filtration unit (Koken, Ltd. Japan) and a Winstat air ionizer BF-X2MB (Shinshido Electrostatic Ltd., Japan). The air filtration unit circulates the limited volume of gas inside the anaerobic chamber quickly, and effectively removes dust particles generated during sample processing. In this manner, clean air conditions are established that are comparable to the air quality in ISO Class 1 clean environments. The ionizer neutralizes surface charge and reduces static attraction of potentially contaminating airborne particles. Subsampling yielded a compact subcore $(2 \mathrm{~cm}$ diameter) that was aseptically drilled out of the center of the WRCs. All further processing steps, including crushing of samples into powder, cell separation and filtration were conducted in a super-clean room at KCC. The super-clean room is equipped with a Floor KOACH Ez that produces horizontal ISO Class 1 quality of laminar airflow from the end wall of the clean space (60). All of the clean experiments were conducted upstream, in front of the KOACH clean units, and electronic equipment (centrifuges, refrigerator, and sonicator) was placed downstream of the clean space. To neutralize the static electricity of the samples, plastic equipment, and gloves (hands), a bar-type sheath-sensing ionizer (SJ-H180, Keyence, Japan) was placed approximately $40 \mathrm{~cm}$ above the working area of the stainless steel laboratory bench, and the static elimination capacity was routinely checked with high-precision electrostatic sensors (SK-H055 and SK-J050, Keyence, Japan) (14).

The presence of airborne particles in the laboratory air of DV Chikyu, in the anaerobic chambers, and in the super-clean room at KCC was monitored throughout the expedition (14). In the shipboard and shorebased workspaces, the concentration of airborne particles was recorded with a Met One HHPC 3+ airborne particle counter (Met One Instruments, Inc.; Grants Pass, Oregon, USA) and with a Biotest particle counter (9303-01BT), respectively. Particle concentrations were determined for three particle size classes $(>0.3,>0.5,>1 \mu \mathrm{m})$. In the shipboard and shore-based anaerobic chambers, particle counts were reduced by up to five orders of magnitude compared to the surrounding laboratory air, and airborne particle concentrations in the vicinity of the work area of the super-clean room at KCC were consistently below the detection limit of the particle counter $\left(<1\right.$ particle $\left.\mathrm{ft}^{-3}\right)(14)$.

To quantify the concentration of airborne microbial cells that may potentially contaminate cores during shipboard core handling, cells in $1 \mathrm{~L}$ of air were counted from the various workspaces. To this end, $1 \mathrm{~L}$ of air was drawn through a $0.22-\mu \mathrm{m}$ polycarbonate membrane in a syringe filter housing (Swinnex Filter Holder, $25 \mathrm{~mm}$, Merck Millipore). Cells on the filter were preserved with formaldehyde fixation solution, treated with SYBR Green I nucleic acid staining solution, and enumerated as described above. Visual inspection of the membranes under the microscope revealed submicrometer-scale particle densities consistent with particle counts in all core processing workspaces. However, in the anaerobic chambers and in the super-clean room at KCC, none of these particles were cells. Overall, our QA/QC measures reduced airborne particle contamination to negligible levels.

Introduction of microbial cells and chemical compounds from equipment and chemicals used during sample processing - During the cutting of cores and processing of samples, sediment came only in contact with precleaned (with $18 \mathrm{M} \Omega$ water) and sterilized tools, such as autoclaved spatulas and ceramic knives, or precombusted $\left(500^{\circ} \mathrm{C}\right.$ for $5 \mathrm{~h}$ ) ceramic pestles and mortars. Tools were replaced whenever potential contamination by contact with a nonsterile surface was suspected. WRCs were packed with end caps that had been cleaned with ethanol, dried in a clean bench, and irradiated with UV light for at least $20 \mathrm{~min}$ prior to use. Interior surfaces of the anaerobic chamber were routinely decontaminated by wiping with RNase AWAY (Thermo Fisher Scientific). In addition, the working surface 
was covered with a fresh sheet of precombusted aluminum foil $\left(500^{\circ} \mathrm{C}\right.$ for $\left.5 \mathrm{~h}\right)$ each time a new WRC was processed. The $\mathrm{N}_{2}$ gas used to store samples under anoxic, $\mathrm{H}_{2}$-free conditions was filtered with a $0.22-\mu \mathrm{m}$ filter to remove potential contamination.

In order to quantify the remaining contamination risk from reagents, tools and airborne particles, 20 negative controls were included into the sample preparation line at KCC. Negative control membranes were prepared by passing saline solution through all cell separation and membrane preparation protocols. On eight out of the 20 negative control membranes, no cells were found in 900 fields of view. The other 12 controls contained up to 3 cells in 900 fields of view. Considering the ratio of reagents used per sediment sample, the analytical blank of cell enumeration was $4.2 \pm 4.0$ cells $\mathrm{cm}^{-3}(N=20)$. Based on this analytical contamination risk, the abundance of microbial cells in sediment samples can be reliably determined above a minimum quantification limit (MQL) of 16 cells $\mathrm{cm}^{-3}$ of sediment ( $95 \%$ confidence level).

\subsection{Remaining contamination risks during Expedition 370 (figs. S6, S7)}

Expedition 370 achieved an unprecedented level of sensitivity for life detection, yet cell concentrations fall below the MQL in $70 \%$ of all 138 samples recovered from $>350 \mathrm{~m}$ depth. The numerous cell counts in the range of the procedural blank testify to the effectiveness of contamination control during sample handling. Most strikingly, cell concentrations average $6.0 \pm 3.1$ cells cm$~^{-3}$ in 32 consecutively taken samples from the zone between 829 and 1020 mbsf (fig. S6). These samples reflect 21 events for the cutting and retrieval of sediment cores from Hole C0023A by rotary core barrel (RCB) coring, and 32 events for the selection, cutting, and processing of WRCs in the shipboard laboratories. In all these samples, cell concentrations do not differ significantly from the procedural blank of $4.2 \pm 4.0 \mathrm{cells} \mathrm{cm}^{-3}(\mathrm{~N}$ $=20$ ). This observation again suggests that the implemented $Q A / Q C$ measures reduced the introduction of microbial cells via drilling fluid and shipboard handling to a negligible level.

Against this background, elevated cell counts in $30 \%$ of the samples recovered from $>350 \mathrm{~m}$ depth call for a rigorous examination of the remaining contamination risks, such as intrusion of drilling fluids into sediment cores along natural and drilling-induced fractures. Quantification of core integrity by X-ray CTimaging does not only confirm the excellent quality of all cell count samples (see above), it also allows for a quantitative comparison of core quality and cell concentrations in all WRCs taken from Hole C0023A. Fig. S7A suggests that cell abundances are not related to the amount of fractures in the sampled core intervals. While $\leq 16$ cells $\mathrm{cm}^{-3}$ were counted in eight samples taken from WRCs with a mean SQ of only $74-90 \%, 11$ out of 34 samples with the highest possible core quality, characterized by a mean SQ of $100 \%$, yielded vegetative cell counts above the MQL. Cell abundances are not correlated with core quality (Spearman correlation $\rho=-0.0095, p(2$-tailed $)=0.929)$. Consequently, elevated cell counts cannot be attributed to drilling induced contamination along fractures. This conclusion is further supported by the lacking relationship between vegetative cell abundance and PFC recovery, which represents the potential contamination of sediment cores by drilling fluid via advection and diffusion (fig. S7B).

\section{Endospores}

Endospores are a dormant form of some members of the bacterial order Firmicutes. Endospores may survive under harsh conditions over geological timescales. Endospores contain the bacterial DNA, ribosomes and large amounts of dipicolinic acid (DPA). In contrast to vegetative cells, endospores cannot 
be visualized with DNA-staining dyes such as SYBR Green I (fig. S5), and thus escape microscopic cell counting methods. We therefore used the biomarker DPA to determine the abundance of endospores in the sediments of Site $\mathbf{C 0 2 3}$. To facilitate a quantitative comparison of endospores and vegetative cells, DPA concentrations were converted into endospore numbers per $\mathrm{cm}^{3}$ of wet sediment. Average concentrations of endospores and vegetative cells were integrated over four depth intervals (table S1), and the relationship between concentrations of endospores and vegetative cells was examined in a temporal framework considering the geothermal history of Site C0023 with the help of a mathematical model.

\subsection{Determination of sedimentary dipicolinic acid (DPA) and endospore concentration (Fig. 1B)}

Sampling for DPA analysis and cell counting were closely coordinated and guided by X-ray CT imaging and visual core inspection as described above. In total, 78 WRCs were collected for DPA analysis from Site $\mathbf{C 0 2 3}$. The cored sediment remained inside the core liners after cutting, and each WRC was packed in a sterile plastic bag and additionally secured in an aluminum bag. Both bags were immediately flushed with $\mathrm{N}_{2}$ and vacuum-sealed, before the sediment cores were frozen with a Cells Alive System freezer (CAS, ref. 61) and stored at $-20^{\circ} \mathrm{C}$ until further treatment.

For post-cruise DPA analysis, a $\sim 4-5 \mathrm{~cm}$ thick disk of sediment was cut from each frozen WRC, and the outer 5-mm layer was removed by scraping, using a flame sterilized chisel. Samples were freeze dried and stored at $-20^{\circ} \mathrm{C}$. For extraction, a $15-\mathrm{mL}$ polypropylene tube was filled with $\sim 1 \mathrm{~g}$ of freeze-dried, homogenized sediment. $4 \mathrm{~mL}$ of Tris buffer (0.2 M; pH = 7.6) was added, because it maximizes the extraction yield in clayey sediments. After vortexing, samples were autoclaved for $20 \mathrm{~min}$ at $121^{\circ} \mathrm{C}$ to extract DPA. After cooling down, $80 \mu \mathrm{L}$ of $2 \mathrm{mM} \mathrm{AlCl}_{3}$ solution was added to precipitate phosphates, which might otherwise quench the fluorescence signal. Tubes were centrifuged for $10 \mathrm{~min}$ at $3000 \mathrm{rpm}$, then supernatants were collected, filtered through 0.2- $\mu \mathrm{m}$ cellulose-acetate filters (Chromafil CA-20/15 $\mathrm{MS}$ ) and stored at $-20^{\circ} \mathrm{C}$ until analysis. Each WRC was extracted in duplicate, and one replicate was spiked with $200 \mathrm{nM}$ DPA as an internal standard to allow for quantification. WRCs were processed in random order. Each batch for extraction included eight WRC samples, and two procedural blanks.

For analysis, $600 \mu \mathrm{L}$ of each sample extract were evaporated to dryness at $50^{\circ} \mathrm{C}$ under a $\mathrm{N}_{2}$ stream and afterwards dissolved in $120 \mu \mathrm{L}$ of a $500 \mathrm{mM} \mathrm{NaHSO}_{4}$ solution ( $\mathrm{pH}=1.2$ ). Detection of DPA closely followed the method described by Fichtel et al. $(62,63)$ using reverse phase high performance liquid chromatography (HPLC) with fluorescence detection. We employed a Phenomenex Gemini 3- $\mu \mathrm{m} \mathrm{C18}$ column $(150 \times 2 \mathrm{~mm})$ and a Thermo FLD-3400 RS detector. $100 \mu \mathrm{L}$ of each sample were injected to a mobile phase consisting of $50 \mathrm{mM} \mathrm{NaHSO}_{4}(\mathrm{pH}=1.2)$ and acetonitrile (97:3) delivered at a flow rate of $0.5 \mathrm{~mL} \mathrm{~min}{ }^{-1}$. After $10 \mathrm{~min}$, a 3-min gradient to $65: 35$ was applied, followed by stable conditions for 1 $\mathrm{min}$, and a reset to initial conditions within $0.5 \mathrm{~min}$. The system was re-equilibrated for $4 \mathrm{~min}$ before the next injection. Fluorescence detection of DPA was achieved by supplying $\mathrm{TbCl}_{3}(50 \mu \mathrm{M})$ post-column via a secondary pump at a flow rate of $0.1 \mathrm{~mL} \mathrm{~min}^{-1}$ (for further details see ref. 64). DPA was identified based on its characteristic fluorescence (emission at $543 \mathrm{~nm}$ after excitation at $271 \mathrm{~nm}$ ) and retention time.

Quantification of DPA was achieved by comparing the integrated peak area of DPA in the unspiked sample to the difference of peak areas between the spiked and unspiked sample, which corresponds to a concentration of $200 \mathrm{nM}$ DPA. DPA abundances were normalized to sediment mass and transferred to endospore concentrations using the empirically determined conversion factor of $2.24 \times 10^{-16} \mathrm{~mol}$ DPA per endospore (64). Each plotted data point represents the mean of duplicate samples. Standard deviations average around $18 \%$ of the reported mean value. 
Sediment dry weight ( $\mathrm{dw}$ ) endospore concentrations were converted to volumetric concentrations by multiplying endospores $\mathrm{g}^{-1} \mathrm{dw}$ with a grain density of $2.7 \mathrm{~g} \mathrm{~cm}^{-3}$ (range of $2.68 \mathrm{~g} \mathrm{~cm}^{-3}$ at $250 \mathrm{mbsf}$ to 2.79 $\mathrm{g} \mathrm{cm}^{-3}$ at 1100 mbsf, cf. Fig. 39B in ref. 14) and then multiplied by (1-porosity) of the sample closest in depth to the endospore sample (MAD data, cf. T06 and T07 in ref. 14).

The detection limit was $2.2 \times 10^{4}$ endospores $\mathrm{cm}^{-3}$. It was defined as the DPA concentration measured in representative sediment samples with a signal-to-noise ratio of 3 . The corresponding peak area equaled a DPA concentration of $3.1 \times 10^{-3} \mathrm{nmol}_{\text {DPA g }}{ }^{-1} \mathrm{dry}$ weight and was converted to endospores $\mathrm{g}^{-1} \mathrm{dw}$ and endospores $\mathrm{cm}^{-3}$ wet weight as described for the samples. For the determination of the detection limit, transformation to wet weight was based on porosity value of 0.58 from the middle of the core $(604.8$ mbsf).

\subsection{Ratio of endospores relative to vegetative cells (table S1)}

In order to determine ratios of endospores to vegetative cells for selected depth intervals of interest, average concentrations of endospores and vegetative cells for these intervals needed to be determined. Average concentration values representative of defined depth intervals (cf. table S1) for both variables were determined by the sum of all integrals between available measurement depths, divided by the length of the depth interval of interest. The upper interval boundary was either $250 \mathrm{mbsf}$ or $350 \mathrm{mbsf}$, i.e., the approximate depth of the uppermost subsurface sample analyzed for endospores and the approximate depth after the major decline of vegetative cell concentrations (cf. Fig. 1). The lower interval boundary was either $1177 \mathrm{mbsf}$ (sediment/basement boundary; endospore data were extrapolated below $1121 \mathrm{mbsf}$ ) or $1121 \mathrm{mbsf}$ (lowest endospore sample). In cases in which no cells or no endospores were detected, we used the analytical blank value of $4.2 \pm 4.0$ cells $\mathrm{cm}^{-3}$ for vegetative cells and the detection limit of $2.2 \times 10^{4} \mathrm{~cm}^{-3}$ for endospores. As this relatively high detection limit for endospores could introduce some artificially high endospore to cell ratios, we also computed an alternative value by setting concentrations in samples with no detection to 4 endospore $\mathrm{cm}^{-3}$, equal to the analytical blank of the vegetative cell data. As shown in table S1, differences between both approaches are minor.

\subsection{Assessing the significance of the two major endospore peaks in relation to low concentrations of vegetative cells (fig. S8)}

The two major endospore peaks centered around $\sim 400$ and $\sim 650$ mbsf are prominent features and raise the question of how they developed in the geological context of Site C0023. Moreover, the orders of magnitude lower concentrations of vegetative cells relative to endospores and the fact that endosporeforming firmicutes commonly account for only a relatively small fraction of the microbial population (6569), call for explanatory scenarios in which the vegetative microbial population has been larger and/or more active in the recent past, at least intermittently. While the elucidation of the exact mechanism leading to the observed predominance of endospores in deeply buried sediments at Site $\mathrm{C} 0023$ goes beyond the scope of this study, the observation of the two major endospore peaks nevertheless calls for an examination of their plausibility and significance.

We rule out that the molecular endospore biomarker DPA accumulated throughout the depositional history, based on its propensity as 2-carboxylated pyridine to decarboxylate upon moderate short-term heating (19). Moreover, it is striking that the position of the two peaks coincide with the upper growth temperatures of mesophiles and thermophiles, suggesting a biological rather than geochemical cause. We therefore constructed a simple quantitative model that explores the accumulation of the observed 
quantities of endospores at Site C0023. For both endospore peaks, we consider as major mechanism triggering sporulation the relatively rapid heating of the sediment column initiated $\sim 0.4 \mathrm{Ma}$ by the drastic increase of sediment accumulation rate (38).

For the shallower peak the increase of sediment temperatures to the upper growth temperature of mesophilic firmicutes provides a conceivable trigger of sporulation. Such a scenario is consistent with the concomitant decrease of vegetative cells in the same sediment horizon (cf. Fig. 1). For the second, larger peak, scenarios starting from current concentration levels of vegetative cells, of which only $1-10 \%$ may be endospore-forming Firmicutes (cf. 65-67) or even less $(68,69)$, appear implausible unless we invoke past events leading to exponential growth and rapid increase of the population of vegetative cells, followed by sporulation and decay of this population. While we cannot categorically rule out such a possibility, it seems inconsistent with the general characteristic of energy starvation encountered by deeply buried microbial communities as well as the geological setting of the horizon, in which no obvious triggers of rapid exponential growth are apparent.

Due to the absence of reasonable triggers of exponential growth linked to the stratigraphy, we therefore consider a mechanism based on the assumption that a background population of thermophilic endospores (17), too low in size to be detected by our DPA-based biomarker approach, is present in deeply buried sediments. The feasibility of a corresponding mechanism explaining the quantitative relationship between endospores and vegetative cells at Site C0023 is explored in figure S8; the underlying model assumes that the above-mentioned background population of endospores germinates upon the onset of accelerated geothermal heating of the sediments to form vegetative cells. The widespread presence of thermophilic endospores has been suggested based on the observation that in Arctic sediments, thermophilic sulfate-reducing bacterial communities can be activated upon heating of the sediments to the growth temperature range of thermophiles (17). Persistence of thermophilic endospores on million-year timescales is also plausible, according to laboratory experiments (70) and provided that temperatures are not excessively high. We consider that temperatures of $50-75^{\circ} \mathrm{C}$ represent the ideal growth range for thermophilic, anaerobic endospore formers, and thus explore the development of the populations of vegetative cells and endospores upon heating of the sediment to $50^{\circ} \mathrm{C}$ (fig. S8). This temperature may have been reached about $0.32 \mathrm{Ma}$ in the sediment interval of 633$827 \mathrm{mbsf}$, representing the more deeply buried endospore peak.

Our model assumes the presence of a background population of 1000 thermophilic endospores $\mathrm{cm}^{-3}$ (red dashed line; this value is lower than estimated background populations in young Arctic surface sediments (17) and was arbitrarily chosen to be lower than our detection limit) and initial germination of vegetative Firmicutes from these endospores at $0.32 \mathrm{Ma}$, when temperatures reached $50^{\circ} \mathrm{C}$; subsequent growth of the Firmicutes populations lasted for $0.2 \mathrm{My}$ until sediment temperatures in this horizon had reached $75^{\circ} \mathrm{C}$.

Accordingly, we can estimate the concentration of vegetative cells $\left(C_{n}\right)$ and the corresponding concentration of endospores for the $\mathrm{n}^{\text {th }}$ generation $\left(\mathrm{S}_{\mathrm{n}}\right)$ with equations 7 and 8 , respectively. From initial germination of the background population of endospores after reaching $50^{\circ} \mathrm{C}$, we assume $\mathrm{C}_{0}$ of $10^{3} \mathrm{~cm}^{-3}$ and $\mathrm{S}_{0}$ of $0 \mathrm{~cm}^{-3}$. We further assume that in each generation, $49 \%$ of the cells sporulate and $51 \%$ double by cell division. This corresponds to a $2 \%$ increase in population size per generation. The sporulation rate of $49 \%$ was chosen to keep concentrations of vegetative cells as low as possible throughout the examined time interval, in accordance with the generally low current concentrations of vegetative cells.

$$
C_{n}=0.51 \times C_{n-1} \times 2
$$




$$
T_{d}=\frac{2 \times 10^{5}}{n}
$$

585 Growth was halted at $75^{\circ} \mathrm{C}$, as this is the upper growth limit for most thermophilic Firmicutes (71), and

586

587

588

589

590

591

592

593

594

595

596

597

598

599

600

601

602

603

604

605

606

607

608

609

610

611

612

613

614

615

616

617

618

619

620

621

622 likewise coincides with the in-situ temperature of the major endospore peak (Fig. 1). This model does not account for the decay of vegetative cells; incorporation of cell decay into the model would consequently increase the number of required generations and lower the generation time. In line with the DPA derived endospore data (Fig. 1), we assume endospore concentrations above $75^{\circ} \mathrm{C}$ to remain roughly constant until they rapidly decline at temperatures above $90^{\circ} \mathrm{C}$.

With this approach, 156 generations were required to arrive at a final concentration $\mathrm{S}_{156}$ of $>1 \times 10^{6}$ endospores within $0.2 \mathrm{My}$, corresponding to a doubling time $\mathrm{T}_{\mathrm{d}}$ of 1290 years (equation 9); the corresponding population of vegetative Firmicutes is $2 \times 10^{4}$ cells $\mathrm{cm}^{-3}$. This modeled final and maximal concentration is higher than the $<10^{3}$ cells $\mathrm{cm}^{-3}$ observed in the modern-day 50 to $75^{\circ} \mathrm{C}$ warm interval; potential reasons include the selection of our model parameters and/or varying concentrations of background endospore input through the sedimentation history and/or different sedimentary conditions between the 400-650 mbsf interval corresponding to the Upper Shikoku Basin and the modern endospore peak within the Lower Shikoku Basin.

\section{Geochemical evidence for microbial activity (Fig. 2)}

Sediment pore-water profiles of microbial substrates, intermediates, and products provide insights into in-situ microbial activity and integrate a variety of processes in time and space. In this study, we present concentration profiles of sulfate, methane, and acetate together with the carbon isotopic composition $\left(\delta^{13} \mathrm{C}\right)$ of methane $\left(\delta^{13} \mathrm{C}-\mathrm{CH}_{4}\right)$ and acetate $\left(\delta^{13} \mathrm{C}\right.$-acetate) (Fig. 2$)$. We compare the relative abundance of methane and ethane (expressed as ratio of methane over ethane, $C_{1} / C_{2}$ ) as indicator of biogenic vs. thermogenic methane sources (Fig. 2). Moreover, we calculate Gibbs free energy yields for various reactions involving methane and acetate, and we employ a diffusion-reaction model for the interpretation of changes in the carbon isotopic composition of pore-water acetate. In the following, we provide details on sampling, analytical methods, and our modeling approach.

\subsection{Sampling}

Shipboard and shore-based gas analyses were conducted on sediment samples that were taken from the freshly cut core and allowed to degas dissolved gases into the headspace of a tightly closed glass vial (head space sampling) (14). For shipboard analysis of light hydrocarbon gases $\left(C_{1}-C_{4}\right), \sim 5 \mathrm{~cm}^{3}$ of sediment were transferred into $20 \mathrm{~mL}$ headspace vials, which were immediately sealed with a silicone septum and metal crimp cap. For shore-based analysis of $\delta^{13} \mathrm{C}_{-} \mathrm{CH}_{4}, \sim 5 \mathrm{~cm}^{3}$ of sediment were transferred into $20 \mathrm{~mL}$ headspace vials, and preserved with $5 \mathrm{~mL}$ of $1 \mathrm{~N} \mathrm{NaOH}$ solution before the vials were sealed with butyl stoppers and crimp caps. Samples were stored at $-20^{\circ} \mathrm{C}$.

Pore-water sulfate and acetate were analyzed in interstitial water samples extracted from 10 to $80 \mathrm{~cm}$ long WRCs, which were cut from core sections with minimal drilling disturbance, selected as described in the expedition report (14) and above (cf. section 4.2). Sediment was extruded from the core liners and prepared for squeezing in a nitrogen-flooded glove bag in order to minimize the oxidation of oxygensensitive species. The outer layer of the sediment cores was carefully removed with a ceramic knife to 
avoid contamination from drilling fluid, and the cleaned sediment was filled into the titanium beakers of the squeezer. Interstitial water was then extracted using a Carver laboratory hydraulic press, which was not in the glove bag. In general, a force up to $30,000 \mathrm{lb}$ was applied. This maximum force was chosen to avoid clay mineral dehydration. However, the force was increased to up to $60,000 \mathrm{lb}$ for a few samples that did not yield sufficient water (reported in Table T13 of the expedition report [14]). The interstitial water was passed through an Advantec 13 100\% alpha cotton cellulose 3- $\mu \mathrm{m}$ filter inside the squeezer (both prewashed with $18 \mathrm{M} \Omega$ water), collected in a 24-mL acid-washed plastic syringe, extruded through a Millipore Millex-LH hydrophilic $0.45-\mu \mathrm{m}$ polytetrafluoroethylene (PTFE) disposable filter and collected into acid-washed high-density polyethylene (HDPE) vials. For shipboard sulfate analysis, an aliquot of the interstitial water samples was diluted 1:200 with $18.2 \mathrm{M} \Omega$ deionized water. Samples for shore-based analysis of acetate were stored in pre-combusted glass vials at $-20^{\circ} \mathrm{C}$. All sampling procedures are described in detail in the expedition report (14).

In the course of the expedition, QA/QC routines revealed a variance in dissolved sulfate concentrations that, based on a diffusion model, could be attributed to the diffusion of sulfate from the core liner fluid into the core. The scatter in sulfate concentrations decreased when thicker layers were removed from the outer surface of sediment cores prior to squeezing. While initially the outer $\sim 3 \mathrm{~mm}$ were scraped off from each sediment surface, $5 \mathrm{~mm}$ and finally $7 \mathrm{~mm}$ were removed after Core $54 \mathrm{R}$ (712.71 mbsf) and Core $83 \mathrm{R}$ ( $864.88 \mathrm{mbsf})$, respectively.

\subsection{Analytical methods}

Methane and higher hydrocarbons - For shipboard analysis of concentrations of methane and higher hydrocarbon gases $\left(C_{2}-C_{4}\right)$, the headspace vials were placed in an Agilent Technologies 7697A headspace sampler, where they were heated to $70^{\circ} \mathrm{C}$ for $30 \mathrm{~min}$ before an aliquot of the headspace gas was automatically injected into an Agilent 7890B GC equipped with a packed column (HP PLOT-Q) and flame ionization detector (FID). He was the carrier gas $\left(10 \mathrm{~cm}^{3} \mathrm{~min}^{-1}\right)$. After injection, the initial column oven temperature of $60^{\circ} \mathrm{C}$ was ramped at a rate of $10^{\circ} \mathrm{C} \mathrm{min}^{-1}$ to $150^{\circ} \mathrm{C}$. Chromatographic response of the FID was calibrated with commercial standards, and the response of the FID was checked on a daily basis as described in the expedition report (14). Based on the analyzed partial pressures of methane in headspace gas samples, the concentrations of dissolved pore-water methane were derived using a mass balance approach (14). The resulting hydrocarbon gas data are reported in Table T21 and T22 of the expedition report (14).

Sulfate - Shipboard analysis of sulfate was conducted using a Dionex ICS-2100 ion chromatograph. The column oven was set at $30^{\circ} \mathrm{C}$. The eluent solution was $40 \mathrm{mM}$ potassium hydroxide. Aliquots of a standard (IAPSO Batch 157 , salinity $=34.994$ ) were used in all analytical batches. In each batch, every diluted sample was analyzed twice. Variations due to temperature-dependent changes in the injected volume and sample dilution were corrected by normalization to chloride, which was determined independently by titration. An IAPSO standard was analyzed after every fifth analysis for drift correction, thus yielding an uncertainty of $0.02 \mathrm{mM}$ for sulfate analysis. All methods and raw data are documented in detail in the expedition report (14, Table T14 in ref. 14).

$\delta^{13} \mathrm{C}-\mathrm{CH}_{4}$ - The carbon isotopic composition of methane was analyzed on shore by isotope ratio monitoring gas chromatography/mass spectrometry (irm-GC/MS), using a Thermo Finnigan Trace GC Ultra connected to a Thermo Finnigan DELTA Plus XP mass spectrometer via a Thermo Finnigan GC combustion III interface. The Trace GC was equipped with a Carboxen column ( $30 \mathrm{~m}$ length, $0.32 \mathrm{~mm}$ inner diameter). The carrier gas was helium $\left(3 \mathrm{~mL} \mathrm{~min}^{-1}\right)$, the split ratio ranged from 1:3 to 1:100 
depending on sample concentration, and the temperatures of the $\mathrm{GC}$ oven and injector were $40^{\circ} \mathrm{C}$ and $200^{\circ} \mathrm{C}$, respectively. The primary standardization was based on multiple injections of reference $\mathrm{CO}_{2}$ from a lab tank $\left({ }^{13} \mathrm{C}=-34.17 \pm 0.1 \%\right.$ ovs. VPDB, $3.0 \pm 0.5 \mathrm{~V}$ at $\left.\mathrm{m} / \mathrm{z} 44\right)$ at the beginning and end of the analysis of each sample. The analytical precision was better than $0.4 \%$ ( $1 \sigma)$.

Acetate and $\delta^{13} \mathrm{C}$-acetate - Concentration and carbon isotopic composition of acetate were analyzed on shore by isotope ratio monitoring high performance liquid chromatography/mass spectrometry (irmHPLC/MS) as described previously (25). The analysis involves chromatographic separation of VFAs on a Thermo Finnigan Surveyor HPLC combined with chemical oxidation of the effluents in a Thermo Finnigan $\mathrm{LC}$ IsoLink interface and subsequent online transfer of the resulting $\mathrm{CO}_{2}$ into a Thermo Finnigan DELTA Plus XP mass spectrometer via open split. Chromatographic separation was achieved with a VA 300/7.8 Nucleogel Sugar $810 \mathrm{H}$ column ( $300 \mathrm{~mm}$ length; $7.8 \mathrm{~mm}$ ID; Macherey-Nagel) equipped with a guard column (CC30/4 Nucleogel Sugar $810 \mathrm{H} ; 30 \mathrm{~mm}$ length; Macherey-Nagel), and $5 \mathrm{mM}$ phosphoric acid as mobile phase with a flow rate of $300 \mu \mathrm{L} \mathrm{min}^{-1}$. The column was kept at room temperature. The quantitative analysis of VFAs is based on the linear correlation between signal area of $\mathrm{m} / \mathrm{z} 44$ recorded by irm-LC/MS and injected amount of carbon (72). For carbon isotope analysis of VFAs, primary standardization on the DELTA Plus XP is based on multiple (three to six) injections of reference $\mathrm{CO}_{2}\left(\delta^{13} \mathrm{C}\right.$ $=-34.3 \pm 0.1 \%$ vs. VPDB, $3.5 \pm 0.5 \mathrm{~V}$ at $\mathrm{m} / \mathrm{z} 44)$ from a tank before and after the analysis of each sample. We calculated the ${ }^{13} \mathrm{C} /{ }^{12} \mathrm{C}$ ratios of the eluting compounds and the corresponding $\delta^{13} \mathrm{C}$-values according to Ricci et al. (73) and Santrock et al. (74), using ion currents of $\mathrm{m} / \mathrm{z} 44$ and $\mathrm{m} / \mathrm{z} 45$ integrated over time for each individual peak and a mean ${ }^{17} \mathrm{O} /{ }^{16} \mathrm{O}$ ratio for each chromatographic run that resulted from the analysis of the $\mathrm{CO}_{2}$ reference peaks. Precision and accuracy were assessed by periodic analysis of standards as described previously (72). Standard deviations for repeated carbon isotope analysis were $<0.6 \%$, and mean $\delta^{13} \mathrm{C}$ values of dissolved VFAs deviated by $<0.6 \%$ from those determined for their salts by elemental analyzer/isotope ratio mass spectrometer (EA/IRMS). The detection limit for carbon isotope analysis of acetate was $10 \mu \mathrm{M}$, i.e. slightly higher than the detection limit of $5 \mu \mathrm{M}$ for quantitative acetate analysis. Samples with acetate concentrations exceeding 1.3 mM were diluted 1:10 with MilliQ water to facilitate accurate analysis.

\subsection{Thermodynamic calculations (Fig. S9)}

The standard Gibbs energy $\left(\Delta \mathrm{G}^{0}{ }^{2}\right.$ insitu $)$ of sulfate-dependent $\mathrm{AOM}\left(\mathrm{CH}_{4}+\mathrm{SO}_{4}{ }^{2-} \rightarrow \mathrm{HCO}_{3}{ }^{-}+\mathrm{HS}^{-}+\mathrm{H}_{2} \mathrm{O}\right)$, sulfate reduction from acetate $\left(\mathrm{SO}_{4}{ }^{2-}+\mathrm{CH}_{3} \mathrm{COO}^{-} \rightarrow \mathrm{HS}^{-}+2 \mathrm{HCO}_{3}{ }^{-}\right)$, sulfate reduction from hydrogen $\left(4 \mathrm{H}_{2}+\right.$ $\left.\mathrm{SO}_{4}{ }^{2-}+\mathrm{H}^{+} \rightarrow \mathrm{HS}^{-}+4 \mathrm{H}_{2} \mathrm{O}\right)$, methanogenesis from acetate $\left(\mathrm{CH}_{3} \mathrm{COO}^{-}+\mathrm{H}_{2} \mathrm{O} \rightarrow \mathrm{CH}_{4}+\mathrm{HCO}_{3}^{-}\right)$, and methanogenesis from hydrogen $\left(4 \mathrm{H}_{2}+\mathrm{HCO}_{3}{ }^{-}+\mathrm{H}^{+} \rightarrow \mathrm{CH}_{4}+3 \mathrm{H}_{2} \mathrm{O}\right)$ (fig. S9) was calculated using the SUPCRT/OBIGT software package (75) and reported thermodynamic data (76-78) for in-situ temperatures estimated from the local geothermal gradient (fig. S4) and a median pressure of $55.8 \mathrm{MPa}$. The energy of reactions at non-standard conditions $\left(\Delta \mathrm{G}_{\mathrm{R}}\right)$ was calculated according to:

$$
\Delta \mathrm{G}_{\mathrm{R}}=\Delta \mathrm{G}^{0} \mathrm{insitu}+\mathrm{R} \times \mathrm{T} \times \ln \mathrm{Q}
$$

where $\mathrm{R}\left(0.008314 \mathrm{~kJ} \mathrm{~mol}^{-1} \mathrm{~K}^{-1}\right)$ is the ideal gas constant, $\mathrm{T}$ (in $\mathrm{K}$ ) is the in-situ temperature, and $\mathrm{Q}$ denotes the activity quotient of the reactants and reaction products. Activities were estimated by multiplying the measured concentration of the species with activity coefficients calculated from an extended version of the Debye-Hückel equation (79) for an ionic strength of $I=0.64$ and in-situ temperatures using the Geochemists Workbench ${ }^{\circ}$ Software (www.gwb.com). In depths where $\mathrm{HS}^{-}$was below detection, we assumed a molar concentration of $0.1 \mu \mathrm{mol} \mathrm{L}^{-1}$. 
Profiles of concentrations of acetate and its carbon isotopic compositions ( $\delta^{13} \mathrm{C}$-acetate) (Fig. $2 \mathrm{C}$ ) indicate effective turnover of acetate in up to $60^{\circ} \mathrm{C}$ hot sediments, minimal utilization of acetate between $60^{\circ} \mathrm{C}$ and $100^{\circ} \mathrm{C}$, and the presence of a biological acetate sink above $100^{\circ} \mathrm{C}$. Dissolved acetate concentrations ([Ac]) are sub-millimolar in sediments of the Upper Shikoku Basin and increase at the transition to the Lower Shikoku Basin where they remain relatively constant, at $9.2 \pm 2.4 \mathrm{mM}$ (Fig. 2). Starting near the Upper and Lower Shikoku Basin interface, $\delta^{13} \mathrm{C}$-acetate is invariable, $-18.8 \pm 0.5 \%$, within the measurement precision ( $0.6 \%$ ) (Fig. $2 \mathrm{C}$ ). This constancy breaks at the transition between the zone of no detectable microbial cells and the deep cell-populated zone. Acetate concentrations decrease while $\delta^{13} \mathrm{C}$ acetate monotonically increases with depth, reaching a maximum measured value of $-7.9 \%$ at 1101 mbsf. This combination of isotope and concentration data implies catabolic acetate utilization.

The interval of invariable $\delta^{13} \mathrm{C}$-values is consistent with production of acetate from isotopically monotonous organic matter, by thermal degradation and possibly fermentation. In contrast, the deep increase of $\delta^{13} \mathrm{C}$-values is consistent with biological utilization of acetate, which favors the ${ }^{13} \mathrm{C}$-depleted acetate isotopologue, leaving the unreacted acetate enriched in ${ }^{13} \mathrm{C}(25,72,80)$. At any depth, the isotopic composition of acetate reflects the composition of the source(s), the isotopic fractionation associated with consumption, and diffusion, which tends to homogenize variations. For a depth interval where there is no significant continuing acetate production and over which diffusive transport is limited, i.e., $\left(\mathrm{L} /(\mathrm{Dt})^{0.5}<1\right.$ (where $\mathrm{D}$ is the effective diffusion coefficient, $\mathrm{L}$ is the length scale and $\mathrm{t}$ is time), $\delta^{13} \mathrm{C}$ acetate is expected to vary linearly with $\ln \left([\mathrm{Ac}] /[\mathrm{Ac}]_{0}\right)$ (where $[\mathrm{Ac}]_{0}$ is the initial acetate concentration), with a slope of the isotope fractionation, $\varepsilon$. In a diffusive steady state system with either zero or first order uptake kinetics, concentrations are zero at the boundary and the slope should be $\varepsilon / 2$. In systems where there is diffusion but steady-state has not been reached, the slope is expected to be between these values.

As expected, if biological uptake caused the acetate depletion in the deep cell populated zone, $\delta^{13} \mathrm{C}$ acetate varies linearly as a function of $\ln \left([\mathrm{Ac}] /[\mathrm{Ac}]_{0}\right)$ (fig. S10). With a best-fit slope of $-7.7 \%$, the corresponding $\varepsilon$ value is ranging from $-7.7 \%$ o to $-15.4 \%$. This is consistent with the range of experimentally determined $\varepsilon$ values associated with biological acetate utilization (26).

We estimated the magnitude of the uptake with a simple model. First, we estimated the magnitude of thermogenic production based on acetate concentrations between $\sim 650$ and $\sim 940 \mathrm{mbsf}$. In this zone of constant $\delta^{13} \mathrm{C}$-acetate, which indicates the lack of uptake, concentrations rise rapidly and then approximately plateau. Since diffusion will only be effective over distances less than approximately $50 \mathrm{~m}$ in this region over the timescales since burial-driven heating began producing acetate $0.4 \mathrm{Ma}$, this plateau implies that the presumably dominantly thermogenic production is rapid as the sediment is heated to the acetate producing temperature window. Production then slows dramatically with further burial and heating, as otherwise concentrations would significantly rise with depth. The total production of acetate in each unit of sediment has thus been approximately $9.2 \pm 2.4 \mathrm{mM}$, while in our deepest sample concentration has been reduced to $3.3 \mathrm{mM}$, which gives an average depletion rate since the time of acetate production $0.4 \mathrm{Ma}$ of approximately $5 \times 10^{-12}$ to $7 \times 10^{-12} \mathrm{~mol} \mathrm{~cm}^{-3} \mathrm{y}^{-1}$. Normalized to the abundance of cells in the cell populated zone $\left(10-100\right.$ cells $\left.\mathrm{cm}^{-3}\right)$, the average uptake rates over the time since acetate was produced are between $5 \times 10^{-14}$ to $7 \times 10^{-13} \mathrm{~mol} \mathrm{cell}^{-1} \mathrm{y}^{-1}$. 


\section{Radiotracer experiments (Fig. 2E)}

Metabolic activity of methanogenesis from $\mathrm{CO}_{2}$ was determined in radiotracer experiments to achieve the highest possible sensitivity. Sediment was amended with seawater medium, traces of hydrogen, and

${ }^{14} \mathrm{C}$-bicarbonate, and incubated in gas-tight headspace vials at representative in-situ temperatures. At the end of the experiments, radioactivity of the methane and bicarbonate pool was determined to quantify the rate of methane production. The resulting methanogenesis rates (MGR $\mathrm{DIC}_{\mathrm{C}}$ ) should be regarded as potential activity.

For radiotracer experiments, one peeled WRC sample (approx. length $10 \mathrm{~cm}$ ) per investigated core was transferred to an anaerobic chamber. In the glove box, additional sediment (ca. 2-3 mm) was removed from the WRC surface with a sterile ceramic knife and discarded. The clean innermost part of the core was chopped off with the knife to create a mixture of very small sediment chips and powder. Approximately $5 \mathrm{~mL}$ of this sediment was placed into a $20-\mathrm{mL}$ crimp vial to which $5 \mathrm{~mL}$ of artificial seawater medium (sulfate-free, $1 \mathrm{mM} \mathrm{NaHCO}_{3}$ ) were added (see recipe below). Three replicate vials were prepared from each WRC. Vials were crimp-sealed with chlorobutyl stoppers (Bellco) and aluminum crimps. After sealing, the vial headspace was flushed with $\mathrm{N}_{2}$ gas to remove any hydrogen and other gases present in the atmosphere of the anaerobic chamber. Subsequently, $40 \mu \mathrm{l} \mathrm{N} 2 / \mathrm{H}_{2}$ gas $(95 \% / 5 \%)$ was injected into each vial to provide approx. $130 \mathrm{nM}$ of dissolved hydrogen in the liquid phase. All vials and stoppers were autoclaved, and solutions were either autoclaved or filtered through sterile syringe filters $(0.22 \mu \mathrm{m}$ pore size) prior to use.

Radiotracer experiments were conducted in the radioisotope van onboard Chikyu. For the determination of $\mathrm{MGR}_{\text {DIC }}$, about $10 \mu \mathrm{L}$ of radiolabeled $\left({ }^{14} \mathrm{C}\right.$ ) $\mathrm{NaHCO}_{3}{ }^{-}$(containing up to $3.7 \mathrm{MBq}$ radioactivity) were injected through the rubber stoppers, and vials were shaken thoroughly. Samples were incubated at temperatures within the in-situ range: $40^{\circ} \mathrm{C}$ for $\leq 360 \mathrm{mbsf}, 60^{\circ} \mathrm{C}$ for $405-585 \mathrm{mbsf}, 80^{\circ} \mathrm{C}$ for $604-775$ mbsf and $95^{\circ} \mathrm{C}$ for $\geq 816 \mathrm{mbsf}$. After 5-10 days of incubation, microbial activity was stopped by injecting $500 \mu \mathrm{L} 50 \% \mathrm{NaOH}(\mathrm{w} / \mathrm{v})$ into each vial, and vials were shaken and shipped to Aarhus University, Denmark, for analysis.

The radiotracer experiments were accompanied by a suite of controls. On-board Chikyu, sediment controls ( $5 \mathrm{~mL}$ sediment mixed with $5 \mathrm{~mL}$ artificial, sulfate-free seawater medium) were incubated without radiotracer addition. Radiotracer was then added after microbial activity was stopped to check for reactions past incubation. In addition, medium controls ( $5 \mathrm{~mL}$ sterile medium, no sediment) and drill fluids ( $5 \mathrm{~mL}$ drill fluid, both seawater and high viscosity samples from the mud tank) were incubated with radiotracer in the same manner as sediment samples to check for non-biological reactions in the medium and biological reactions in the drill fluid, respectively. Moreover, an additional set of killed sediment controls was prepared post-cruise by irradiating sediment with $18 \mathrm{kGy}$. After irradiation, samples were incubated and processed like regular sediment samples.

Artificial seawater medium for sediment slurry incubations was prepared as follows. The subsequent salts were added to a 2-L glass bottle: $400 \mathrm{mg} \mathrm{KH}_{2} \mathrm{PO}_{4}, 500 \mathrm{mg} \mathrm{NH}_{4} \mathrm{Cl}, 1 \mathrm{~g} \mathrm{MgCl} 2 \times 6 \mathrm{H}_{2} \mathrm{O}, 1 \mathrm{~g} \mathrm{KCl}, 300 \mathrm{mg}$ $\mathrm{CaCl}_{2} \times 2 \mathrm{H}_{2} \mathrm{O}, 50 \mathrm{~g} \mathrm{NaCl}$. The bottle was filled up to $2 \mathrm{~L}$ with ultrapure $\mathrm{H}_{2} \mathrm{O}$. Some drops of Resazurin solution ( $100 \mathrm{mg}$ Resazurin in $100 \mathrm{~mL} \mathrm{H} \mathrm{H}_{2} \mathrm{O}$ ) were added. The bottle was covered (but not completely closed) with a screw cap and autoclaved. After autoclaving, the medium was purged with $\mathrm{N}_{2}$ gas while still hot $\left(>60^{\circ} \mathrm{C}\right)$. During purging, $10 \mathrm{~mL}$ of sterile filtered $\mathrm{NaHCO}_{3}$ solution $\left(84 \mathrm{~g} \mathrm{NaHCO}_{3}\right.$ in $\left.100 \mathrm{ml} \mathrm{H}_{2} \mathrm{O}\right)$ were added to the medium. The $\mathrm{pH}$ was adjusted to 7.5 with sterile filtered $6.5 \% \mathrm{HCl}(\mathrm{v} / \mathrm{v})$ or $\mathrm{NaOH}$ solution $(\mathrm{w} / \mathrm{w})$. The bottle was then closed with a sterile butyl stopper and a screw cap and $\sim 3 \mathrm{~mL}$ of 
sterile filtered $\mathrm{Na}_{2} \mathrm{~S}$ solution ( $1.2 \mathrm{~g} \mathrm{Na}_{2} \mathrm{~S}$ in $100 \mathrm{~mL} \mathrm{H}_{2} \mathrm{O}$ ) was added through the stopper with a syringe to reduce the medium. Reduction was confirmed by discoloration of Resazurin.

In each crimped vial, the amount of radioactive methane $\left({ }^{14} \mathrm{CH}_{4}\right)$ was determined using a method involving purging of the headspace, followed by combustion of ${ }^{14} \mathrm{CH}_{4}$ from the headspace to ${ }^{14} \mathrm{CO}_{2}$, and scintillation counting (29). More specifically, the headspace was flushed with $\mathrm{CO}_{2}$-free air at $25 \mathrm{~mL} \mathrm{~min}^{-1}$ for $20 \mathrm{~min}$. In the evolving gas stream, ${ }^{14} \mathrm{CH}_{4}$ was oxidized to ${ }^{14} \mathrm{CO}_{2}$ in a quartz glass tube containing $\mathrm{CuO}$ pellets, heated to $900^{\circ} \mathrm{C} .{ }^{14} \mathrm{CO}_{2}$ from the oven exhaust gas was trapped in $5 \mathrm{~mL}$ Carbosorb (Perkin Elmer). The Carbosorb was mixed with $5 \mathrm{~mL}$ scintillation cocktail (Permafluor, PerkinElmer) and radioactivity of ${ }^{14} \mathrm{CO}_{2}$ was quantified on a TriCarb 2900TR liquid scintillation analyzer (PerkinElmer). The entire gas line was made of glass, which does not absorb $\mathrm{CO}_{2}$, and the gas stream was subjected to a wash-step in $1 \mathrm{M}$ $\mathrm{NaOH}$ before combustion to prevent trace amounts of labeled DIC from penetrating into the oven. The efficiency of $\mathrm{CH}_{4}$ combustion was tested by adding known amounts of non-radioactive $\mathrm{CH}_{4}$ to a reaction vessel and following its conversion to $\mathrm{CO}_{2}$ in the exhaust gas. For this, $500 \mu \mathrm{L}$ of the exhaust gas was regularly injected into a gas chromatograph equipped with a $0.9-\mathrm{m}$ packed silica gel column of $3.1 \mathrm{~mm}$ inner diameter and a flame ionization detector (SRI 310C, SRI Instruments). Conversion efficiencies were always $>99 \%$.

After extraction of ${ }^{14} \mathrm{CH}_{4}$, a subsample of the sediment slurry (100 to $250 \mu \mathrm{L}$ ) was transferred into a new glass vial, crimp capped with butyl rubber stoppers, and acidified with $2 \mathrm{~mL} \mathrm{of} \mathrm{HCl}(6 \mathrm{M})$ to determine the remaining $\left[{ }^{14} \mathrm{C}\right]$-DIC in the sediment. All produced ${ }^{14} \mathrm{CO}_{2}$ was flushed out of the vial headspace with $\mathrm{N}_{2}$ at $25 \mathrm{~mL} \mathrm{~min}{ }^{-1}$ for $35 \mathrm{~min}$ and trapped in $5 \mathrm{~mL}$ Carbosorb. The radioactivity of ${ }^{14} \mathrm{CO}_{2}$ was counted in $5 \mathrm{~mL}$ scintillation cocktail (Permafluor, PerkinElmer) on a TriCarb 2900TR liquid scintillation analyzer (PerkinElmer).

MGR ${ }_{\text {DIC }}$ were calculated similar to (29):

$$
\operatorname{MGR}_{\mathrm{DIC}}=\left(\mathrm{A}_{\mathrm{CH} 4} /\left[\mathrm{A}_{\mathrm{CH} 4}+\mathrm{A}_{\mathrm{DIC}}\right]\right) \times[\mathrm{DIC}] \times 1.08 \times \rho /(\mathrm{t} \times \mathrm{m})
$$

if

$$
\mathrm{A}_{\mathrm{CH} 4}>\left[\mathrm{b}_{\mathrm{c}}+\left(3 \times \sigma_{\mathrm{bc}}\right)\right]
$$

where $A_{C H 4}$ is the radioactivity (counts per minute $=\mathrm{CPM}$ ) of $\mathrm{CH}_{4}$ at the end of the incubation, $A_{D I C}$ is the radioactivity (CPM) of DIC at the end of the incubation, $[D I C]$ is the amount (pmol) of DIC in the sample medium based on the DIC concentration in the medium $(0.677 \mathrm{mM})$ and in the natural sediment porewater, 1.08 is the correction factor for the expected isotopic fractionation (81), $\rho$ is the bulk sediment density $\left(\mathrm{g} \mathrm{cm}^{-3}\right), t$ is the incubation time $(\mathrm{d}), m$ is the sediment mass $(\mathrm{g}), b_{c}$ is the scintillation counter blank signal and $\sigma_{b c}$ is the standard deviation of the blank signal. ${ }^{14} \mathrm{CH}_{4}$ radioactivity determined in controls (sediment controls, medium controls, drill fluid, killed sediment controls) was within or close to levels of scintillation counter blanks. A conservative minimum quantification limit for biological tracer turnover of $0.094 \mathrm{pmol} \mathrm{CH}_{4} \mathrm{~cm}^{-3} \mathrm{~d}^{-1}$ was calculated from the average activity measured in the killed control incubations plus 3 times the standard deviation. The down-hole profile of potential methanogenesis rates in Fig. 2E shows averages and standard deviations of three replicates (table S2). 


\section{References}

35. A. Taira, I. Hill, J.V. Firth et al., Proceedings of the Ocean Drilling Program, Initial Reports, 131. (Ocean Drilling Program, College Station, Texas, 1991). http://dx.doi.org/10.2973/odp.proc.ir.131.1991

36. R. Harris et al., A synthesis of heat flow determinations and thermal modeling along the Nankai Trough, Japan. J. Geophys. Res.-Solid Earth 118, 2687-2702 (2013).

37. F. Inagaki, M. Kinoshita, A. Ijiri, K. Akiyama, V.B. Heuer, K. Homola, C. Li, T. Morisawa, Y. Morono, D. Pan, T. Sun, M.-Y. Tsang, T. Toki, and IODP Expedition 370 Scientists. JAMSTEC KR18-04 cruise report: Recovery of 1.5 years-temperature observatory data and shallow piston-core sediments from IODP Site C0023. KAIREI KR1804 Cruise Data, JAMSTEC, pp. 1-21, (2018). doi:10.17596/0001270. http://www.godac.jamstec.go.jp/darwin/cruise/kairei/kr18-04/e

38. K. Hagino, the Expedition 370 Scientists, Data report: calcareous nannofossils from the middle Miocene to Pleistocene, IODP expedition 370 Site C0023. In: V.B. Heuer, F. Inagaki, Y. Morono, Y. Kubo, L. Maeda (Eds.), The Expedition 370 Scientists, Temperature Limit of the Deep Biosphere off Muroto. Proceedings of the International Ocean Discovery Program, 370, College Station, TX (International Ocean Discovery Program) (2018)

39. P. Costa Pisani, M. Reshef, G. Moore, Targeted 3-D prestack depth imaging at Legs 190-196 ODP drill sites (Nankai Trough, Japan). Geophys. Res. Lett. 32 (2005).

40. G. A. Spinelli et al., Diagenesis, sediment strength, and pore collapse in sediment approaching the Nankai Trough subduction zone. Geol. Soc. Am. Bull. 119, 377-390 (2007).

41. K. Gamage, E. Screaton, Characterization of excess pore pressures at the toe of the Nankai accretionary complex, Ocean Drilling Program sites 1173, 1174, and 808: Results of one-dimensional modeling. J. Geophys. Res.-Solid Earth 111, 13 (2006).

42. T. Tsuji, H. Tokuyama, P. Costa Pisani, G. Moore, Effective stress and pore pressure in the Nankai accretionary prism off the Muroto Peninsula, southwestern Japan. Journal of Geophysical Research: Solid Earth 113, (2008).

43. H. Tobin, P. Vannucchi, M. Meschede, Structure, inferred mechanical properties, and implications for fluid transport in the décollement zone, Costa Rica convergent margin. Geology 29, 907-910 (2001).

44. H. J. Tobin, D. M. Saffer, Elevated fluid pressure and extreme mechanical weakness of a plate boundary thrust, Nankai Trough subduction zone. Geology 37, 679-682 (2009).

45. D. R. Faulkner et al., A review of recent developments concerning the structure, mechanics and fluid flow properties of fault zones. J. Struct. Geol. 32, 1557-1575 (2010).

46. K. M. Brown, D. M. Saffer, B. A. Bekins, Smectite diagenesis, pore-water freshening, and fluid flow at the toe of the Nankai wedge. Earth Planet. Sci. Lett. 194, 97-109 (2001).

47. P. Henry, L. Jouniaux, E. J. Screaton, S. Hunze, D. M. Saffer, Anisotropy of electrical conductivity record of initial strain at the toe of the Nankai accretionary wedge. Journal of Geophysical Research: Solid Earth 108, (2003).

48. M. Kastner et al, 32. Geochemnical and isotopic evidence for fluid flow in the western Nankai subduction zone Japan. Proceedings of the Ocean Drilling Program. Sci Results 131, 397-413 (1993).

49. A. J. Spivack, M. Kastner, B. Ransom, Elemental and Isotopic Chloride Geochemistry and Fluid Flow in the Nankai Trough. Geophys. Res. Lett. 29, 6-1-6-4 (2002).

50. S. Tonai et al., A New Method for Quality Control of Geological Cores by X-Ray Computed Tomography: Application in IODP Expedition 370. Frontiers in Earth Science 7, (2019). 
51. E.C. Bullard, Heat flow in South Africa. Proc. R. Soc. London, Ser. A, 173, 474-502 (1939). doi:10.1098/rspa.1939.0159

52. E. Buckingham, On Physically Similar Systems; Illustrations of the Use of Dimensional Equations. Physical Review 4, 345-376 (1914).

53. M. Heesemann et al., Data report: testing and deployment of the new APCT-3 tool to determine in situ temperatures while piston coring. In: Riedel M, Collett TS, Malone MJ, et al. (Eds.) Proceedings of the Integrated Ocean Drilling Program, 311. (Washington, DC, Integrated Ocean Drilling Program Management International, 2006). doi:10.2204/iodp.proc.311.108.2006

54. M. Kinoshita, H. Fukase, S. Goto, T. Toki, In situ thermal excursions detected in the Nankai Trough forearc slope sediment at IODP NanTroSEIZE Site C0008. Earth, Planets and Space 67, 16 (2015).

55. Y. Morono, F. Inagaki, Chapter Three-Analysis of Low-Biomass Microbial Communities in the Deep Biosphere. Advances in Applied Microbiology 95, 149-178 (2016).

56. Y. Morono, T. Terada, J. Kallmeyer, F. Inagaki, An improved cell separation technique for marine subsurface sediments: applications for high-throughput analysis using flow cytometry and cell sorting. Environ. Microbiol. 15, 2841-2849 (2013).

57. Kallmeyer, J., Smith, D.C., D'Hondt, S.L. and Spivack, A.J. New cell extraction procedure applied to deep subsurface sediments. Limnology and Oceanography: Methods 6, 236-245 (2008).

58. Y. Morono, T. Terada, N. Masui, F. Inagaki, Discriminative detection and enumeration of microbial life in marine subsurface sediments. ISME Journal 3, 503-511 (2009).

59. B. Lomstein, A. Langerhuus, S. D'Hondt, B. Jørgensen, A. Spivack, Endospore abundance, microbial growth and necromass turnover in deep sub-seafloor sediment. Nature 484, 101-104 (2012).

60. Y. Morono et al., Assessment of Capacity to Capture DNA Aerosols by Clean Filters for Molecular Biology Experiments. Microbes and Environments 33, 222-226 (2018).

61. Y. Morono et al., Intact preservation of environmental samples by freezing under an alternating magnetic field. Environmental Microbiology Reports 7, 243-251 (2015).

62. J. Fichtel, J. Köster, J. Rullkötter, H. Sass, High Variations in Endospore Numbers within Tidal Flat Sediments Revealed by Quantification of Dipicolinic Acid. Geomicrobiol. J. 25, 371-380 (2008).

63. J. Fichtel, J. Koster, B. Scholz-Bottcher, H. Sass, J. Rullkotter, A highly sensitive HPLC method for determination of nanomolar concentrations of dipicolinic acid, a characteristic constituent of bacterial endospores. J. Microbiol. Methods 70, 319-327 (2007b).

64. J. Fichtel, J. Koster, J. Rullkotter, H. Sass, Spore dipicolinic acid contents used for estimating the number of endospores in sediments. FEMS Microbiol. Ecol. 61, 522-532 (2007).

65. J. F. Biddle, S. Fitz-Gibbon, S. C. Schuster, J. E. Brenchley, C. H. House, Metagenomic signatures of the Peru Margin subseafloor biosphere show a genetically distinct environment. Proc. Natl. Acad. Sci. U. S. A. 105, 10583-10588 (2008).

66. J. C. Fry, R. J. Parkes, B. A. Cragg, A. J. Weightman, G. Webster, Prokaryotic biodiversity and activity in the deep subseafloor biosphere. FEMS Microbiol. Ecol. 66, 181-196 (2008).

67. D. Zhu, S. H. Tanabe, C. Yang, W. Zhang, J. Sun, Bacterial community composition of South China Sea sediments through pyrosequencing-based analysis of 16S rRNA genes. PloS one 8, e78501 (2013).

68. F. Inagaki et al., Biogeographical distribution and diversity of microbes in methane hydrate-bearing deep marine sediments, on the Pacific Ocean Margin. Proc. Natl. Acad. Sci. U. S. A. 103, 2815-2820 (2006). 
69. M. Kawai, I. Uchiyama, H. Takami, F. Inagaki, Low frequency of endospore-specific genes in subseafloor sedimentary metagenomes. Environmental Microbiology Reports 7, 341-350 (2015).

70. W. L. Nicholson, Using thermal inactivation kinetics to calculate the probability of extreme spore longevity: Implications for paleomicrobiology and lithopanspermia. Orig. Life Evol. Biosph. 33, 621-631 (2003).

71. P. De Vos, G. Garrity, D. Jones, N. R. Krieg, W. Ludwig, F. A. Rainey, K. H. Schleifer, W. B. Whitman, Eds., Bergey's Manual of Systematic Bacteriology: Volume 3: The Firmicutes (Springer, New York, 2009).

72. V. Heuer et al., Online $\delta^{13} \mathrm{C}$ analysis of volatile fatty acids in sediment/porewater systems by liquid chromatography-isotope ratio-mass spectrometry. Limnology and Oceanography: Methods 4, 346-357 (2006).

73. M. P. Ricci, D. A. Merritt, K. H. Freeman, J. M. Hayes, Acquisition and processing of data for isotope-ratiomonitoring mass spectrometry. Org. Geochem. 21, 561-571 (1994).

74. J. Santrock, S. A. Studley, J. M. Hayes, Isotopic Analyses Based on the Mass-Spectrum of Carbon-Dioxide. Anal. Chem. 57, 1444-1448 (1985).

75. J. W. Johnson, E. H. Oelkers, H. C. Helgeson, SUPCRT92: A software package for calculating the standard molal thermodynamic properties of minerals, gases, aqueous species, and reactions from 1 to 5000 bar and 0 to 1000 C. Computers \& Geosciences 18, 899-947 (1992).

76. E. L. Shock, H. C. Helgeson, Calculation of the thermodynamic and transport properties of aqueous species at high pressures and temperatures: Correlation algorithms for ionic species and equation of state predictions to $5 \mathrm{~kb}$ and $1000^{\circ} \mathrm{C}$. Geochim. Cosmochim. Acta 52, 2009-2036 (1988).

77. E. L. Shock, H. C. Helgeson, Calculation of the thermodynamic and transport properties of aqueous species at high pressures and temperatures: Standard partial molal properties of organic species. Geochim. Cosmochim. Acta 54, 915-945 (1990).

78. E. L. Shock, Organic acids in hydrothermal solutions; standard molal thermodynamic properties of carboxylic acids and estimates of dissociation constants at high temperatures and pressures. Am. J. Sci. 295, 496-580 (1995).

79. H. C. Helgeson, Thermodynamics of hydrothermal systems at elevated temperatures and pressures. Am. J. Sci. 267, 729-804 (1969).

80. V. B. Heuer, M. Krüger, M. Elvert, K.-U. Hinrichs, Experimental studies on the stable carbon isotope biogeochemistry of acetate in lake sediments. Org. Geochem. 41, 22-30 (2010).

81. L. K. Hansen, R. Jakobsen, D. Postma D, Methanogenesis in a shallow sandy aquifer, Røm $\varnothing$, Denmark. Geochim Cosmochim Acta 65, 2925-2935 (2001). 


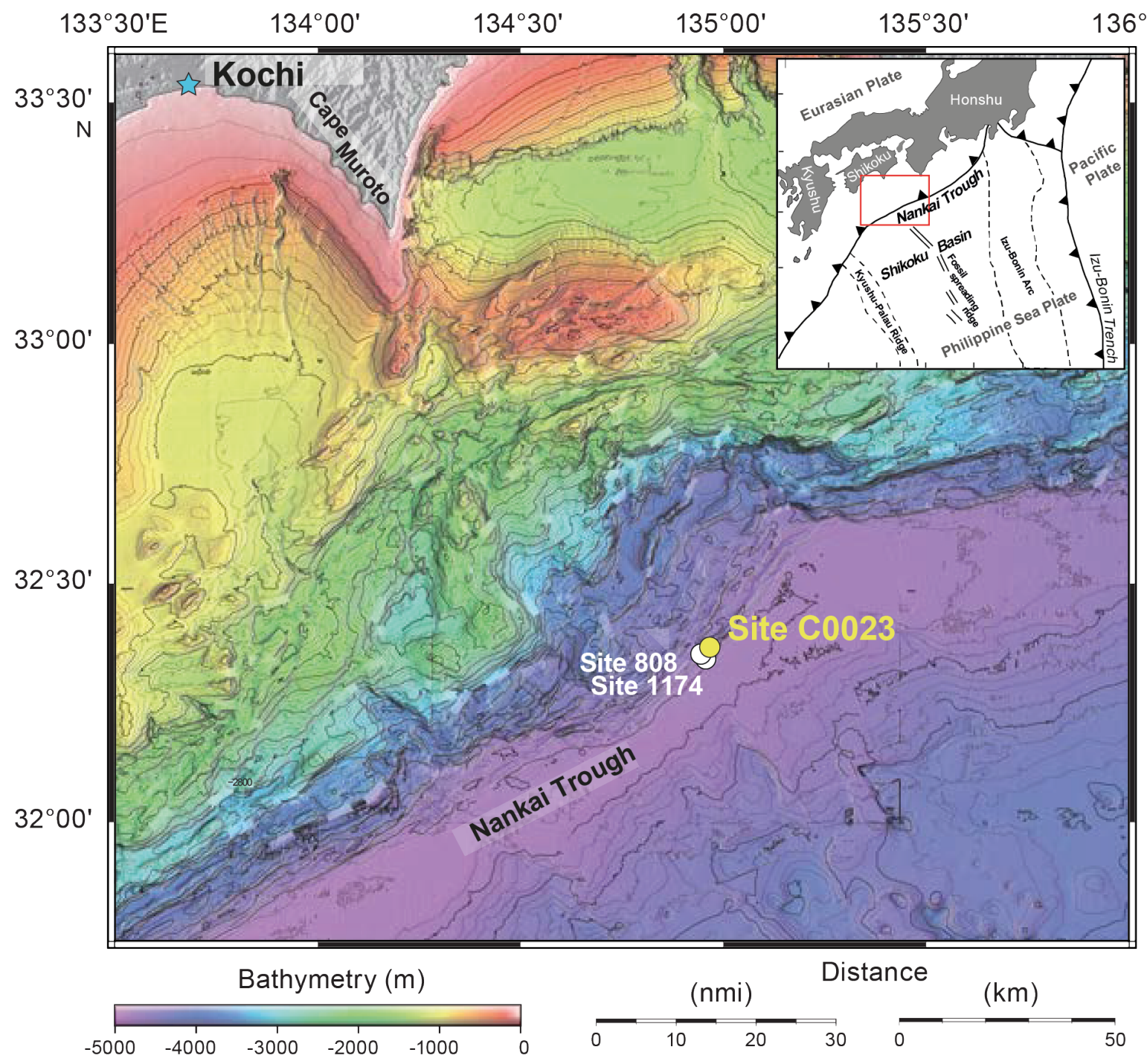

Fig. S1. Bathymetric map showing IODP Site C0023 drilled by the DV Chikyu in 2016 (IODP Expedition 370) off Cape Muroto, Japan, together with previously existing ODP Sites 808 and 1174 drilled by the DV JOIDES

Resolution in 1990 and 2000, respectively. Inset map shows the location (red square) within the context of the general tectonic configuration of the Japanese Island system. (Modified from ref. 14). 


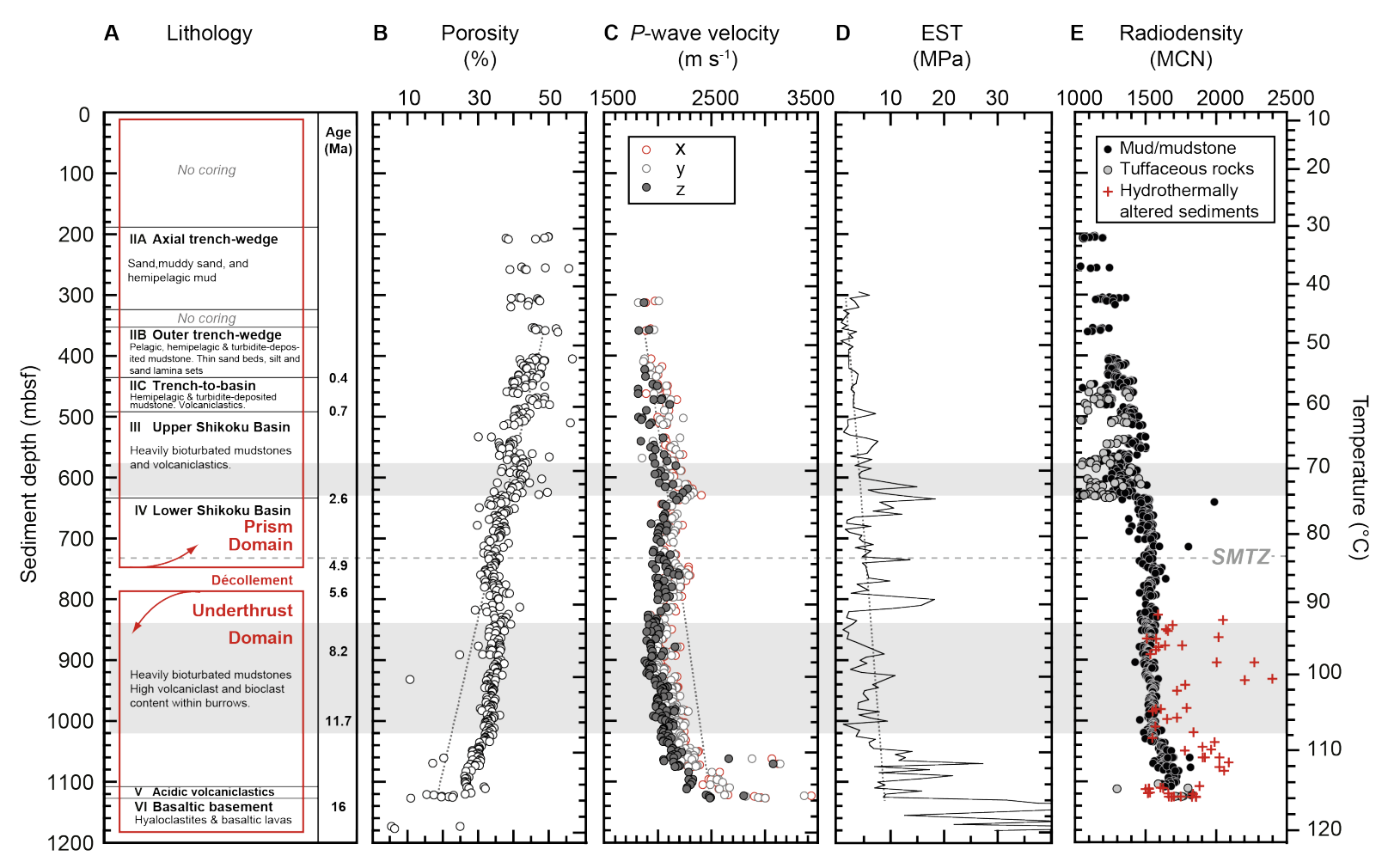

Fig. S2. Depth profiles of sedimentological properties at IODP Site C0023. (A) Lithostratigraphy, tectonic domains, and age information. Major lithological facies (black) are given together with core observations used to constrain formation boundaries (modified from ref. 14). Three tectonic domains (red) are separated based on deformation structures, i.e. an upper domain that comprises the prism, cut by low angle thrusts, the décollement zone at 758$796 \mathrm{mbsf}$, consisting of relatively thin, characteristically brecciated fault zones that are alternating with several meter thick intact zones, and an underthrust domain with extensional faulting and no thrust fault zones (14). The age model results from biostratigraphic studies based on calcareous nannofossil assemblages (38). (B) Porosities, inferred from moisture and density measurements of discrete sediment and rock samples, generally decrease with increasing depth. However, a distinct reversal of this trend (dotted line) occurs across and below the décollement (modified from ref. 14). (C) $P$-wave velocities, i.e. the speed at which ultrasonic sound waves pass through intact sediment cores in three-dimensional space $(x, y, z)$, inversely reflect the porosity profile in general, except for a positive excursion of $P$-wave velocities from the down-hole trend (dotted line) at $\sim 630 \mathrm{mbsf}$, pointing to a stiffening of the fine to coarse tuff and tuffaceous muds in this interval (modified from ref 15). (D) Equivalent strength (EST) is a measure for the in-situ strength of the geological formation, which is deduced from drilling parameters. Positive EST excursions from the down-hole trend (dotted line) show distinctly elevated mechanical strength in the tuff-rich sediments around $\sim 630 \mathrm{mbsf}$, while negative EST excursions reveal a mechanically weak zone below the décollement (modified from ref. 33). (E) The radiodensity profile was derived from continuous logging of sediment cores by X-ray computed tomography (XCT), with average values of quality controlled mean $\mathrm{CT}$ number (MCN) in lithological intervals logged by visual core description (modified from ref. 50). In general, radiodensity increases with depth due to the compaction of mud and mudstones (black symbols). Negative and positive excursions reflect and record the presence of porous tuff layers (gray symbols) and dense hydrothermal mineral assemblages (red symbols), respectively. Gray shading indicates zones where concentrations of both vegetative cells and endospores were below the detection limits of the employed methods in all investigated samples (cf. Fig. 1). The horizontal dashed gray line indicates the location of the sulfate-methane transition zone (SMTZ) at $~ 730$ mbsf (cf. Fig. 2). 


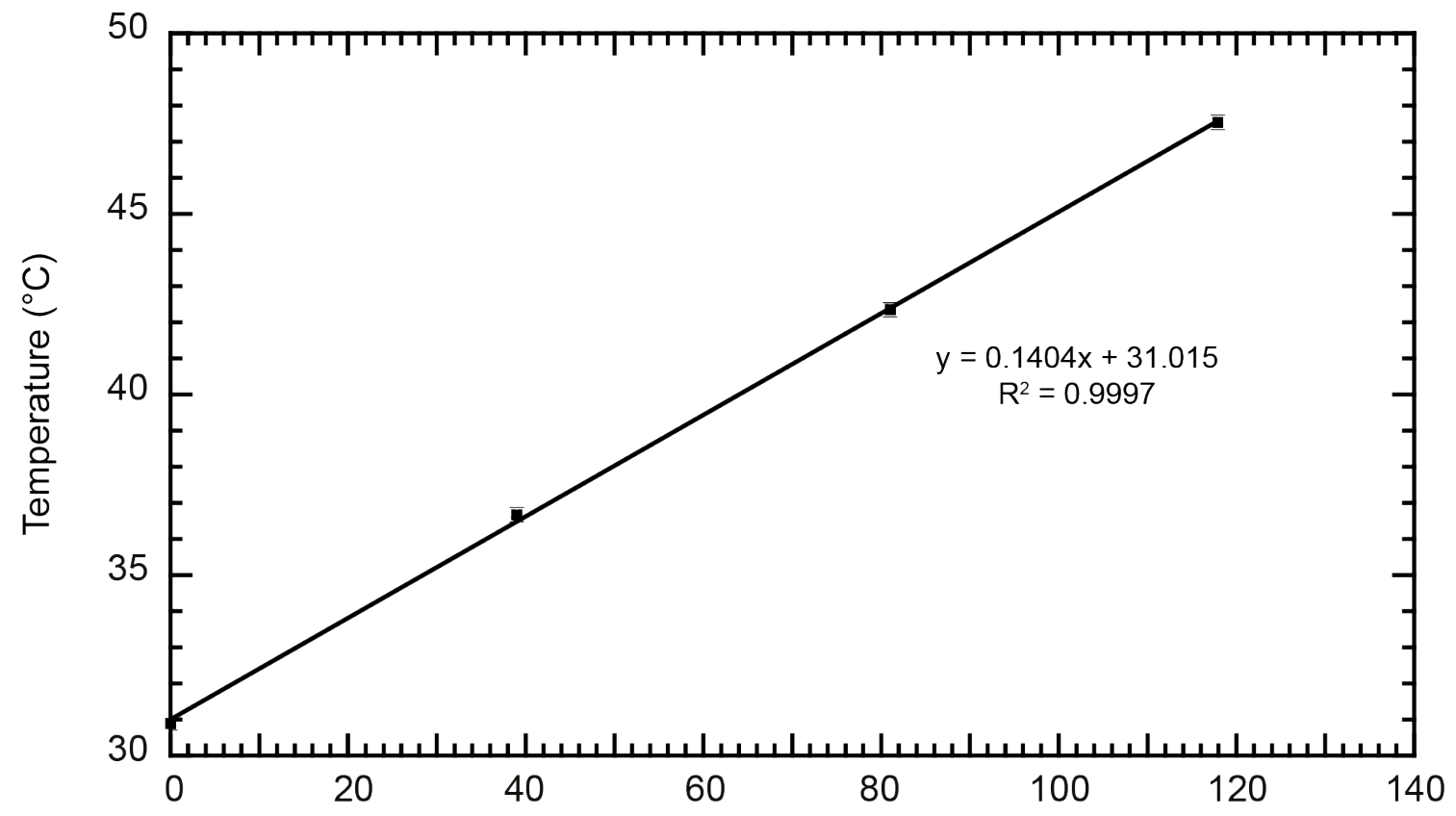

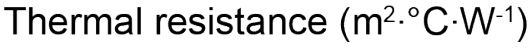

Fig. S3. Heat flow estimate for IODP Site C0023. Measured in-situ temperature vs. thermal resistance, $\sum_{i=0}^{N}\left(\frac{\Delta z_{i}}{k(z)_{i}}\right)$. The slope of the line is equal to $-q$, the negative of the heat flow, $-0.1404 \mathrm{~W} \mathrm{~m}^{-2}(51)$. The $90 \%$ confidence limit of the heat flow is $0.005 \mathrm{~W} \mathrm{~m}^{-2}$. The error bars are the reported uncertainties of the measured temperature, $0.2 \%$. 


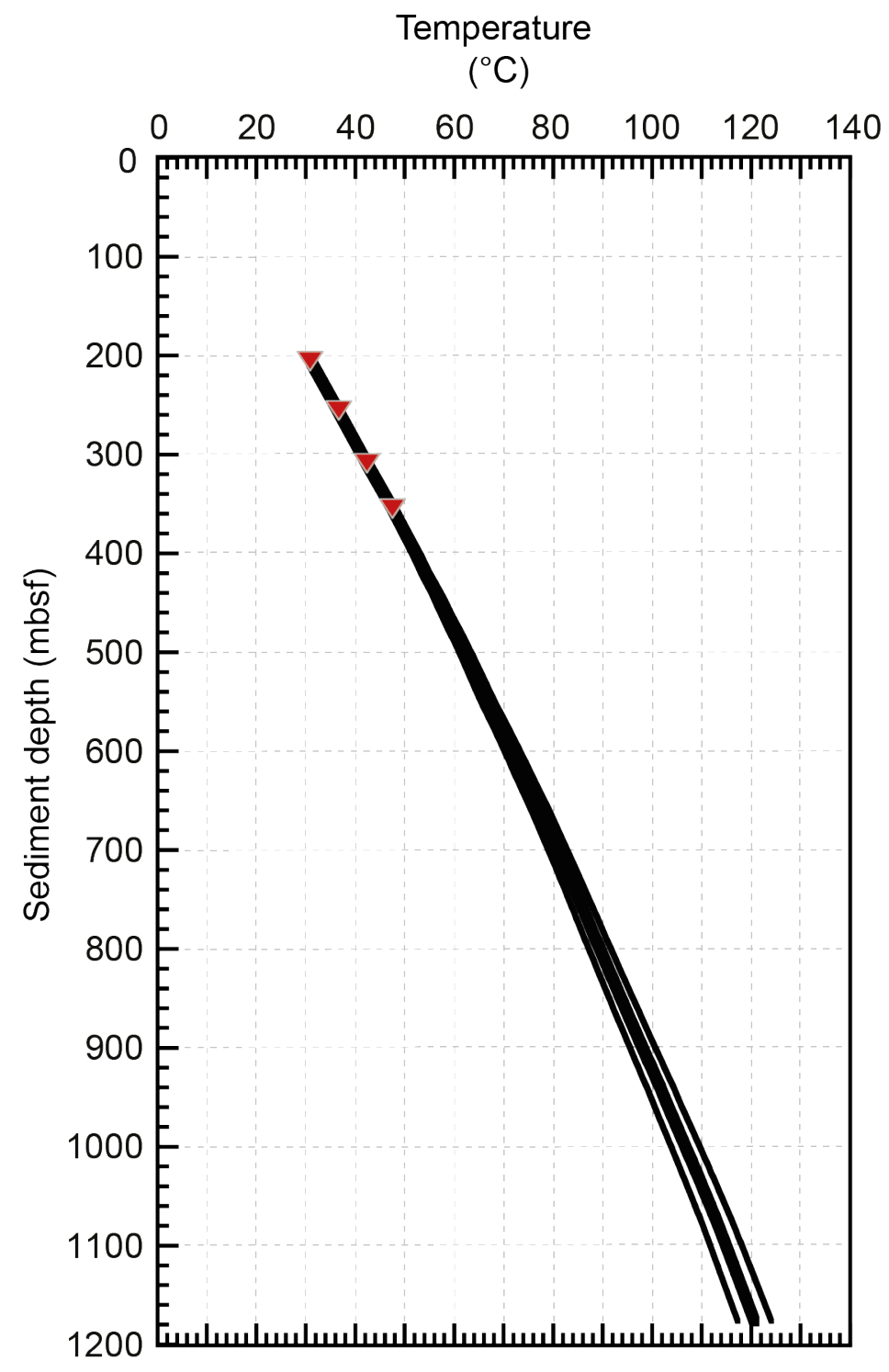

Fig. S4. Temperature profile at Site C0023. In-situ temperatures were determined based upon measured heat flow, thermal conductivities and application of the Bullard equation (equation 2) (51). The thick line is the best estimate and the thin lines represent the $90 \%$ confidence limits. The red triangles are in-situ temperatures measured by APCT-3 tool. 

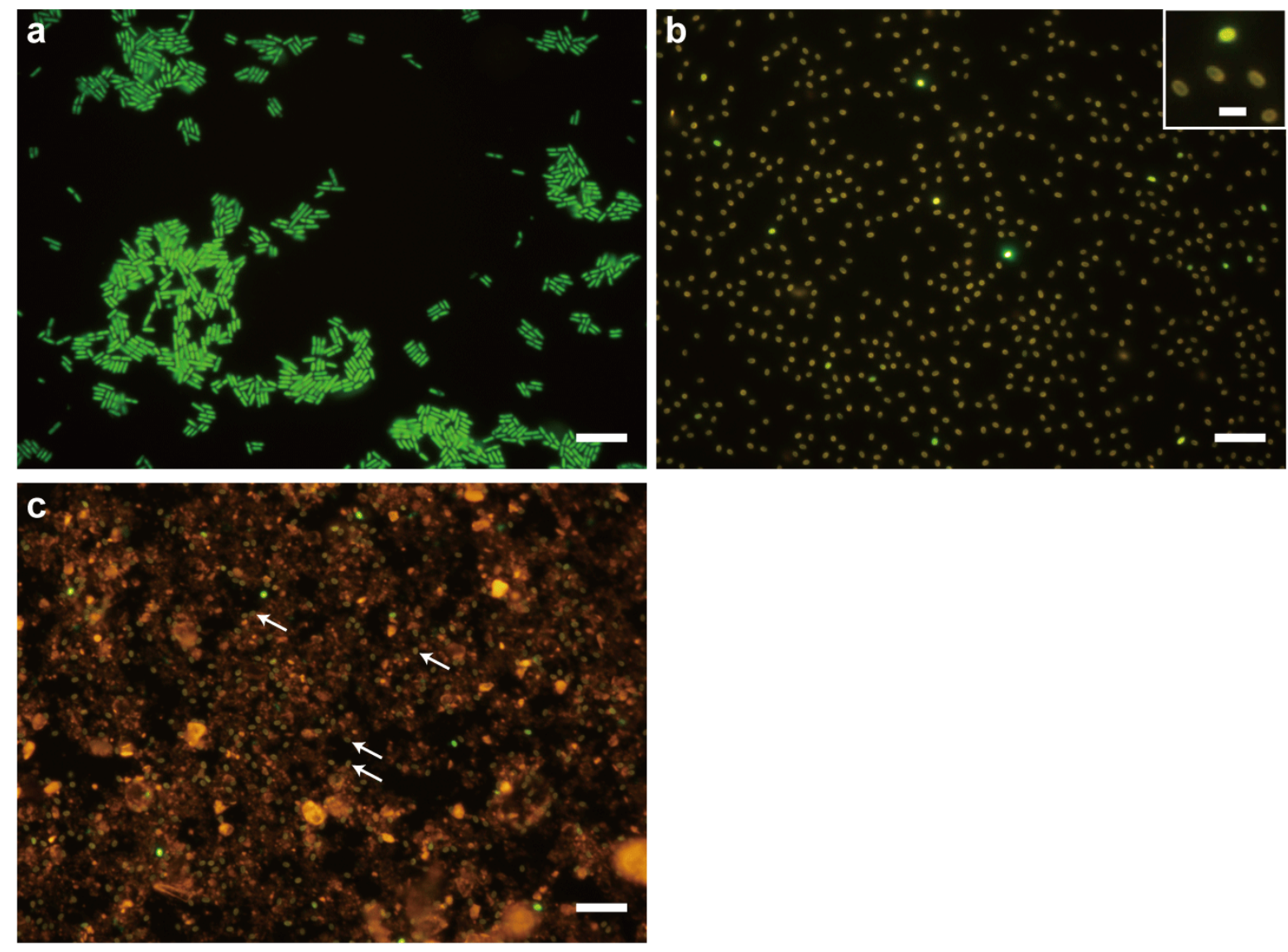

Fig. S5. SYBR Green I staining of vegetative cells (a) and endospores (b) of Bacillus subtilis NBRC13719. Close-up of the spores are shown in white box of (b). In (c), endospores were mixed in sterilized sediment prior to staining by SYBR Green I. Typical yellowish endospores, which are difficult to distinguish from sediment particles, are indicated by white arrows. Bars are $10 \mu \mathrm{m}(2 \mu \mathrm{m}$ in the white box of (b)). 


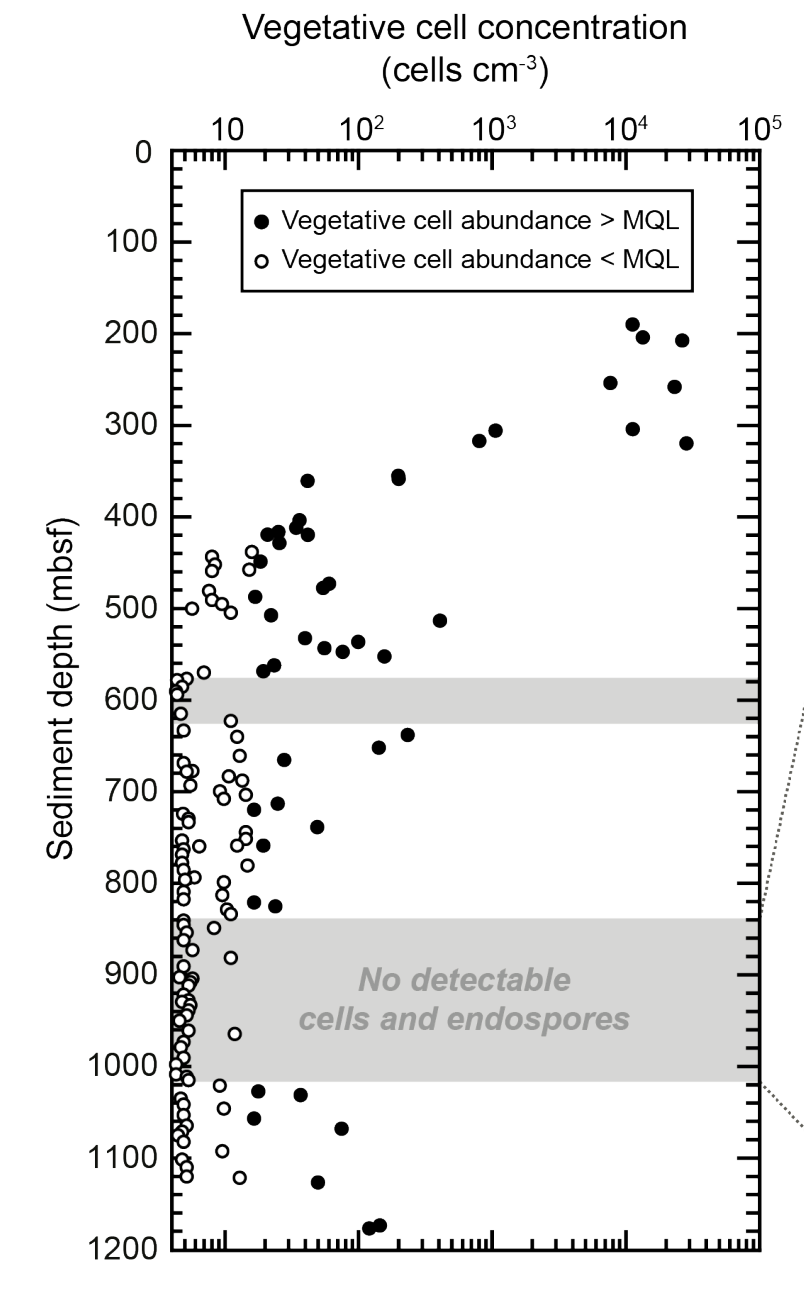

Vegetative cell concentration (cells $\mathrm{cm}^{-3}$ )

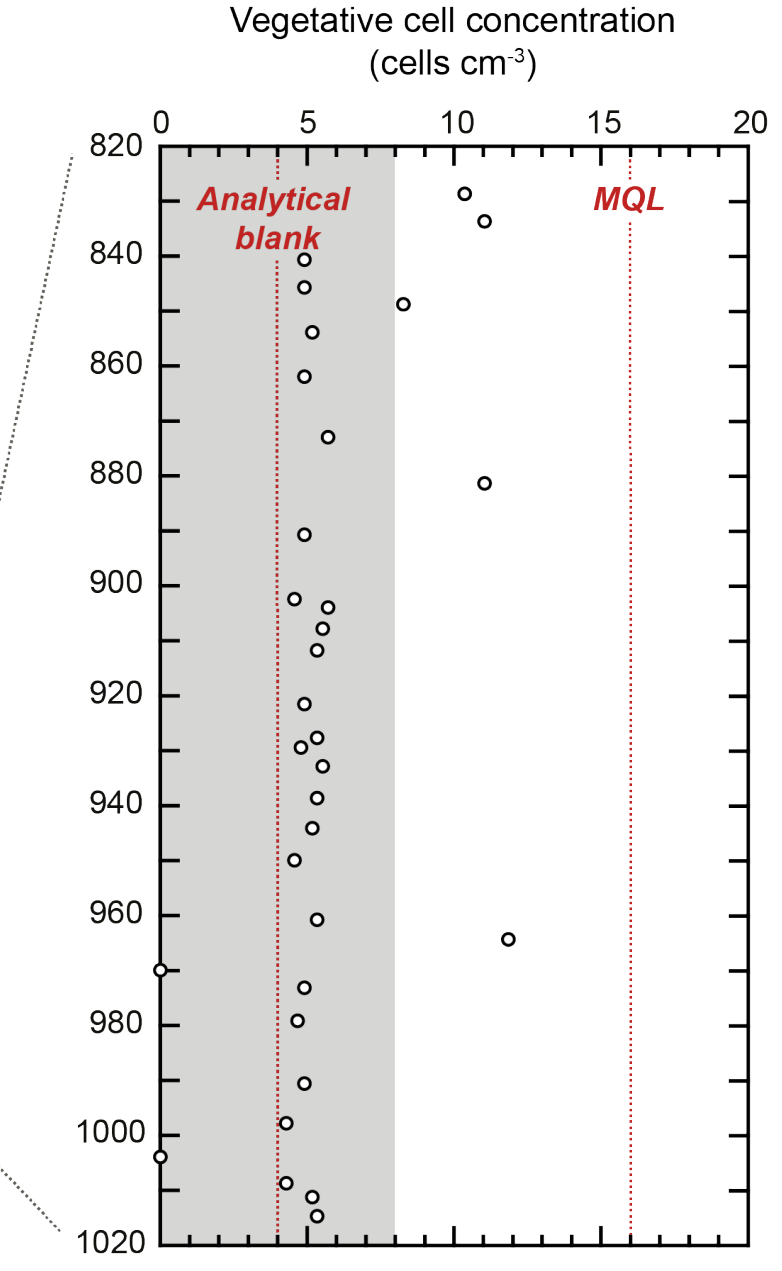

Fig. S6. Absence of contaminant cells from drilling fluids in low biomass samples recovered from IODP Site

C0023. Concentrations of microbial cells fluorescently stained with SYBR Green I fall in the range of the analytical blank ( $4.2 \pm 4.0$ cells $\mathrm{cm}^{-3} ; \mathrm{N}=20$ ) or remain below the minimum quantification limit (MQL) of $16 \mathrm{cells} \mathrm{cm}^{-3}$ in 32 samples retrieved from 829 to 1020 mbsf. This finding shows that the introduction of contaminant cells was negligible during cutting, retrieval and processing of 21 successively taken rotary core barrel (RCB) cores on board DV Chikyu. 
A

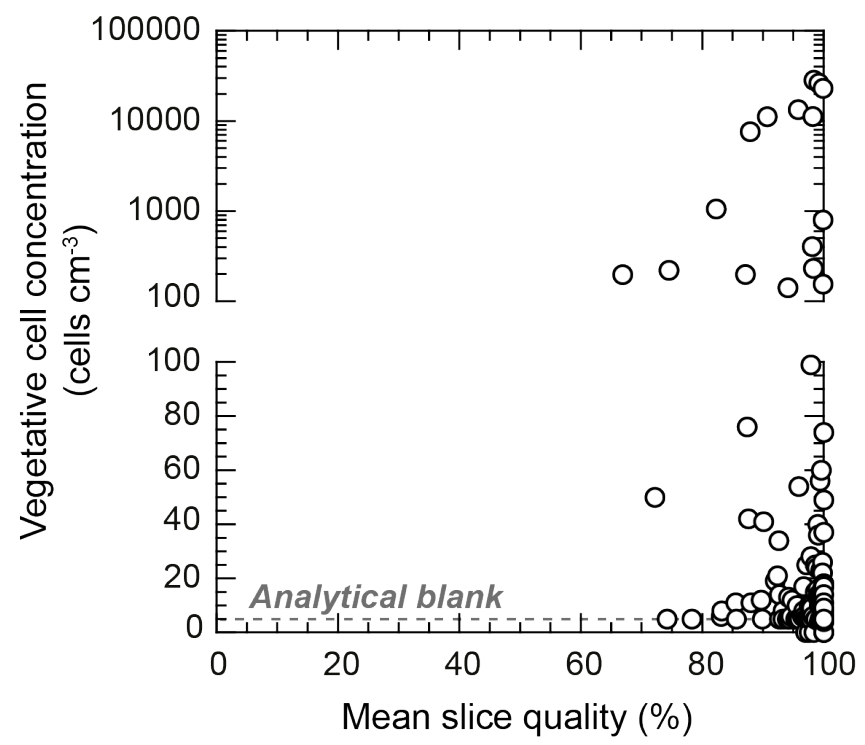

B $\quad$ PFC tracer
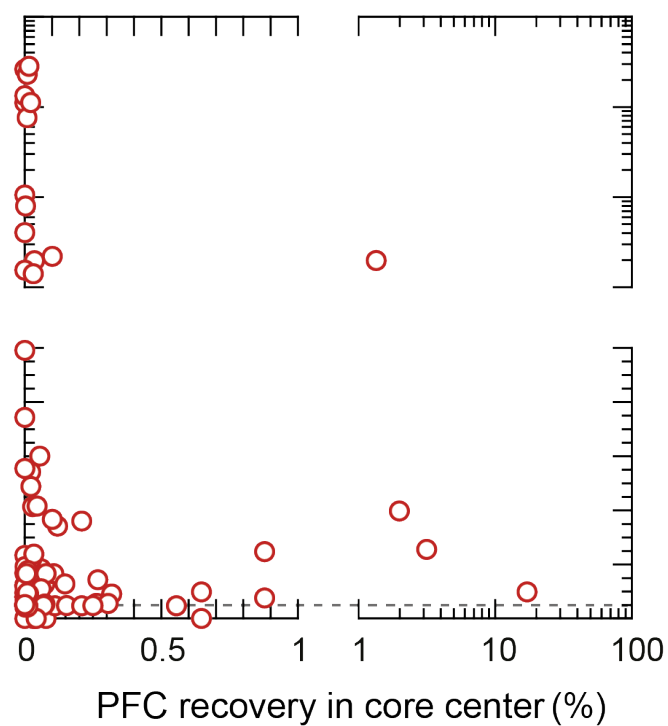

Fig. S7 Impact of drilling on the concentration of vegetative cells in samples from Site C0023. (A) Sample quality was assured using $\mathrm{X}$-ray $\mathrm{CT}$ imaging for the selection of undisturbed core intervals, and controlled based on a quality assessment of individual $0.625 \mathrm{~mm}$ thick X-ray CT slice images. A mean slice quality of $100 \%$ in the sampled $\sim 30 \mathrm{~cm}$ long core intervals represents the highest possible core quality. The lack of relation between mean slice quality and vegetative cell abundance shows that contamination due to the introduction of microbial cells along drilling induced fractures is negligible in high quality cores. (B) Established routines for contamination testing were applied to monitor the potential intrusion of drilling fluid into the cores with the perfluorocarbon (PFC) tracer perfluoromethylcyclohexane. PFC recovery normalizes the PFC concentration measured in the center part of an individual core to the average PFC concentration in the outer parts of the cores, which had been in direct contact with drilling fluid. A PFC recovery of $0 \%$ in the core center represents the lowest risk of drilling induced contamination. The lack of a relationship between PFC recovery and vegetative cell abundance indicates the absence of contamination due to diffusion or advection of drilling fluids. The dashed line represents the analytical blank of cell enumeration $\left(4.2 \pm 4.0\right.$ cells $\left.\mathrm{cm}^{-3}\right)$. 


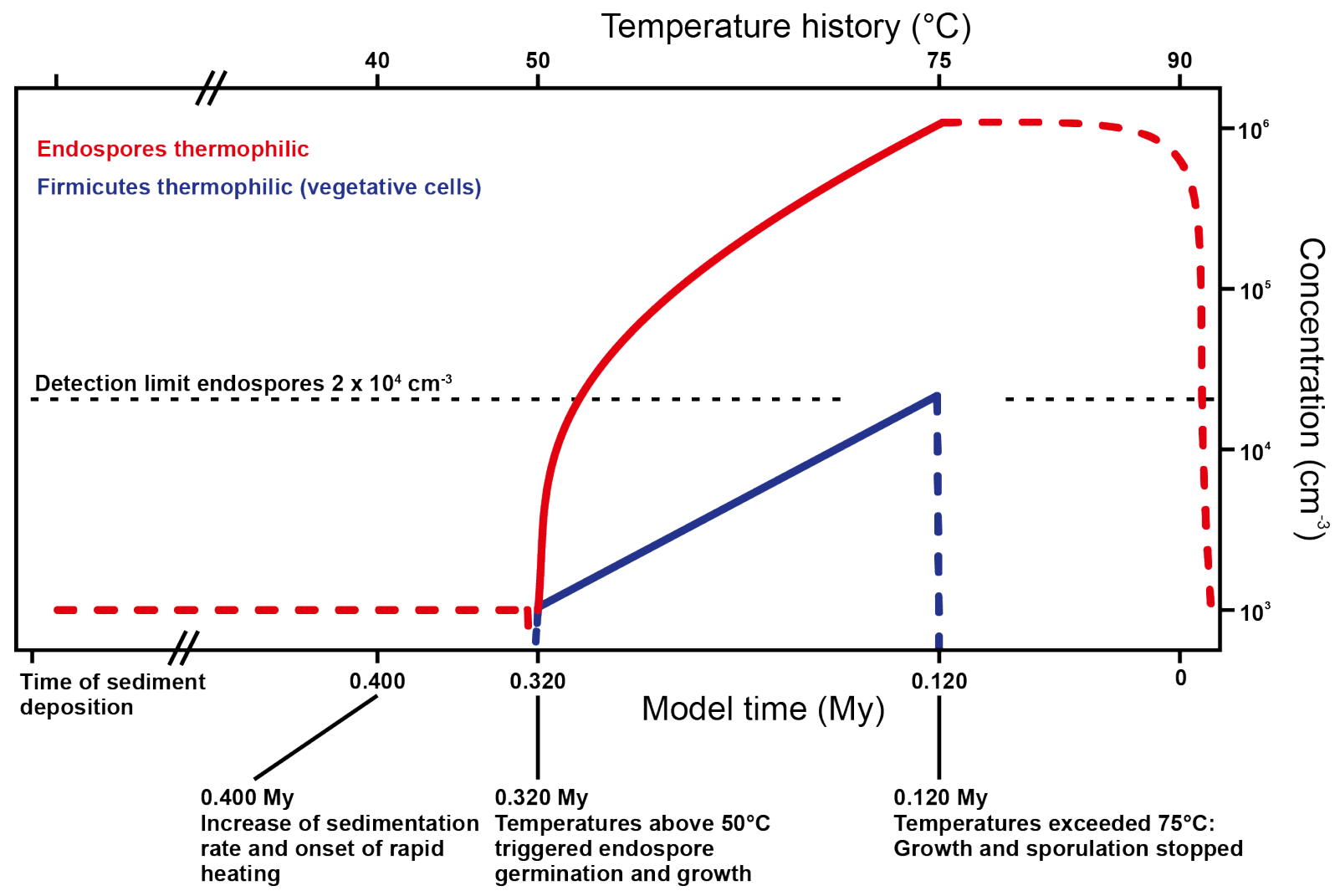

Fig. S8. Validation of the observed accumulation of endospores (> $1 \times 10^{6}$ endospores $\mathrm{cm}^{-3}$; Fig. 1) within the sediment interval corresponding to the major endospore peak between 633-827 mbsf at Site C0023. Depicted is the hypothetical temporal history of the concentrations of thermophilic endospores (solid red line) and vegetative Firmicutes (solid blue line) in the sediments corresponding to this peak through the time period characterized by intensified geothermal heating. Red and blue dashed lines are schematic and do not represent modeling outputs. High accumulation rates of trench sediments in the last $0.4 \mathrm{My}$ caused rapid, linear heating of the sediments at a rate of $\sim 125^{\circ} \mathrm{C} \mathrm{My}^{-1}$. Our model assumes the presence of a background population of 1000 thermophilic endospore $\mathrm{cm}^{-3}$ (red dashed line; this value is lower than estimated background populations in young Arctic surface sediments (17) and was arbitrarily chosen to be lower than our detection limit) and initial germination of vegetative Firmicutes from these endospores at $0.32 \mathrm{Ma}$, when temperatures reached $50^{\circ} \mathrm{C}$; subsequent growth of the Firmicutes populations lasted for $0.2 \mathrm{My}$ until sediment temperatures in this horizon had reached $75^{\circ} \mathrm{C}$. Further details on the model parameters are presented in section 5.3 of the supplementary text. This model shows that the formation of the large endospore population $\left(>1 \times 10^{6}\right.$ endospore $\left.\mathrm{cm}^{-3}\right)$ from germination of a small background population of thermophilic endospores and subsequent growth is plausible based on a set of reasonable assumptions such as a growth temperature range of $50-75^{\circ} \mathrm{C}$ for thermophiles and doubling time of 1290 years for vegetative cells, while still maintaining a relatively low vegetative cell population of below $\sim 2 \times 10^{4} \mathrm{cells} \mathrm{cm}^{-3}$. 


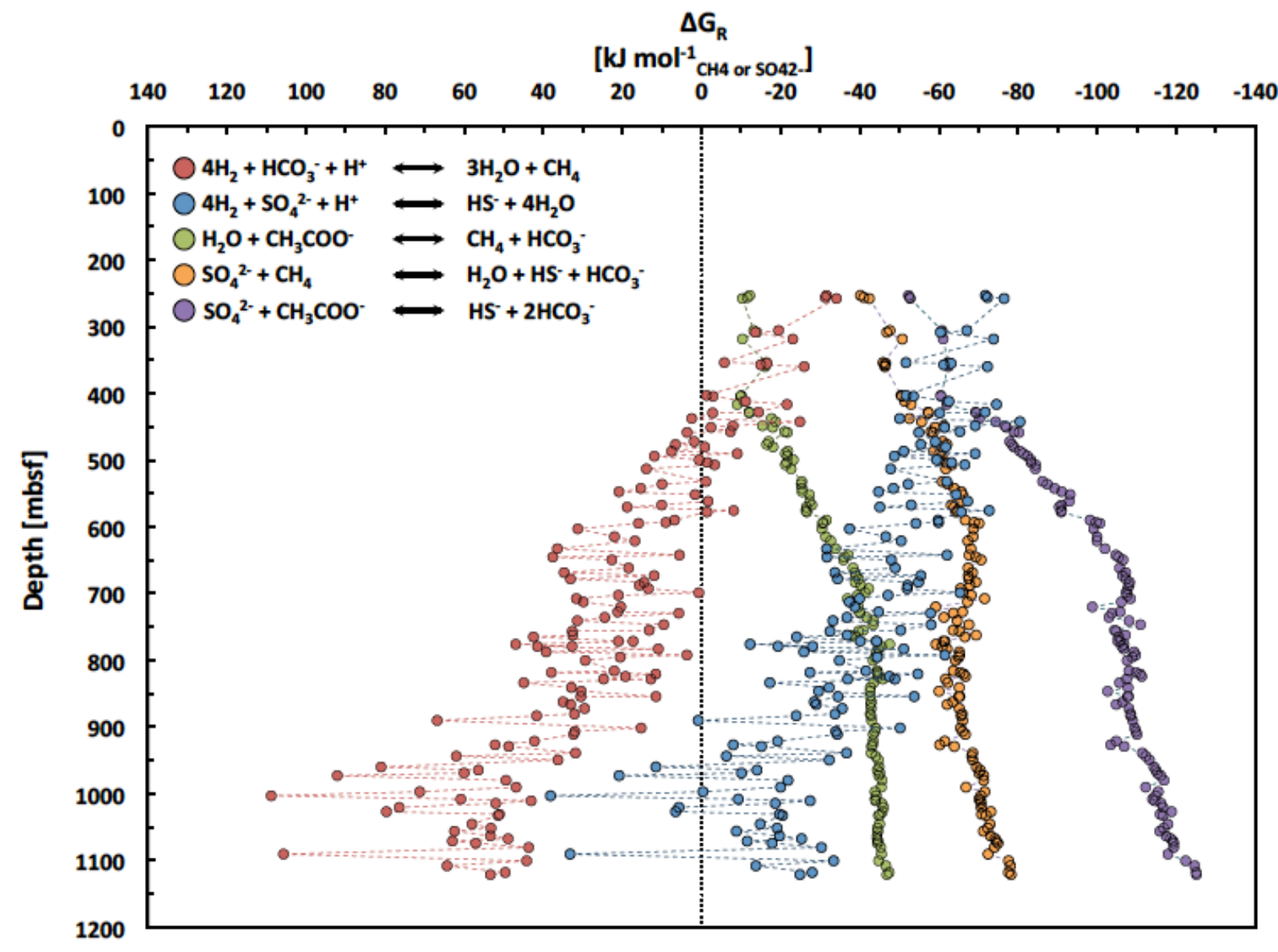

Fig. S9. Calculated Gibbs free energy yields of methanogenesis from hydrogen, sulfate reduction from hydrogen, methanogenesis from acetate, sulfate-dependent AOM, and sulfate reduction from acetate, in sediments at Site C0023. 


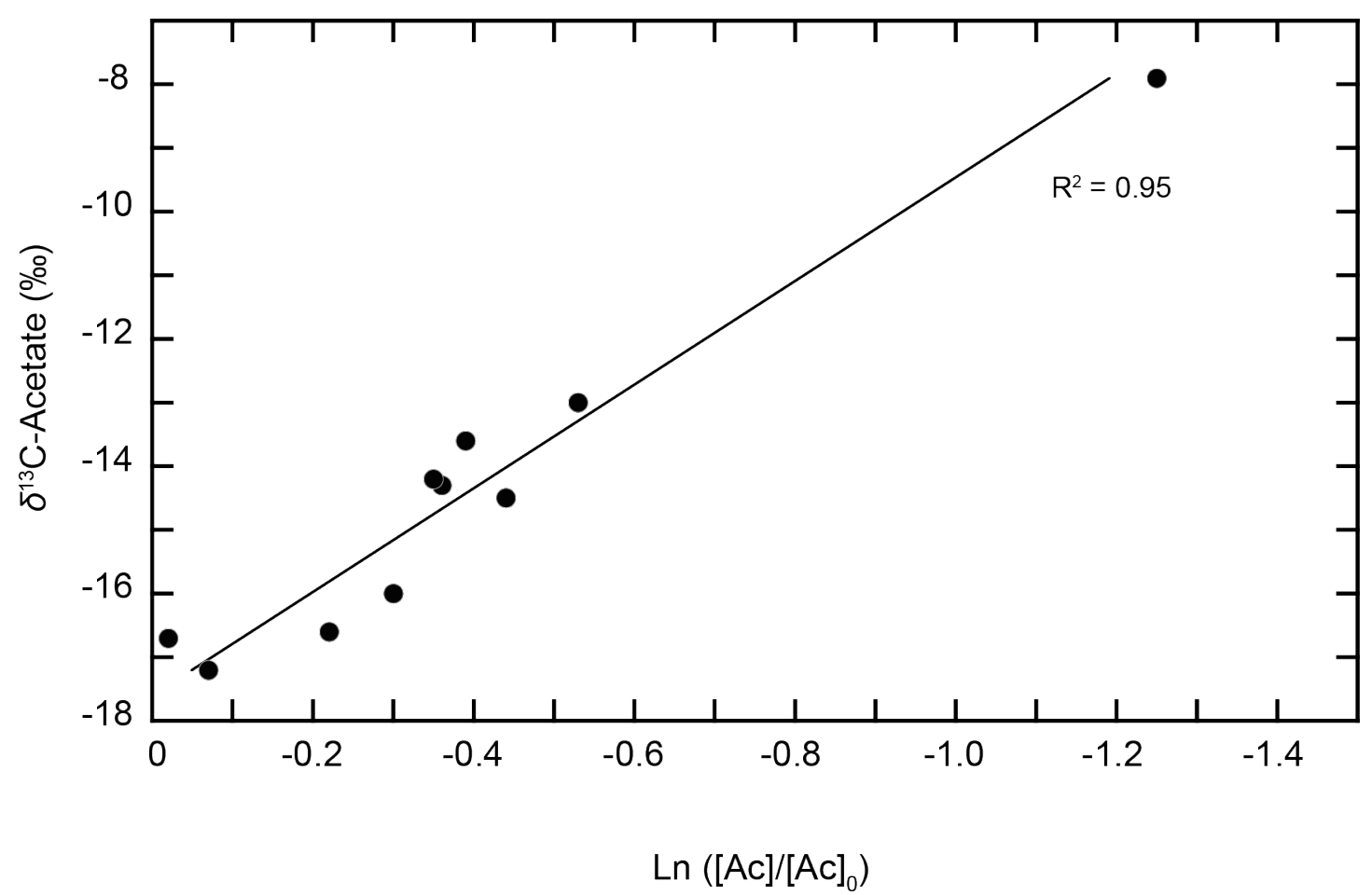

Fig. S10. $\delta^{13} \mathrm{C}$-acetate diffusion-reaction model. At the bottom of Hole C0023A, at 961-1101 mbsf, acetate concentrations $[\mathrm{Ac}]$ decrease and $\delta^{13} \mathrm{C}$-acetate varies linearly as a function of $\ln \left([\mathrm{Ac}] /[\mathrm{Ac}]_{0}\right)$, where $[\mathrm{Ac}]_{0}$ is the acetate concentration in the overlying stagnant acetate pool (i.e. a measured concentration of $11.7 \mathrm{mM}$ at 929.71 mbsf, close to the upper range of average acetate concentrations of $9.2 \pm 2.4 \mathrm{mM}$ at 593.45-945.21 mbsf, $\mathrm{N}=47$ ). This relationship indicates biological uptake of acetate. The best-fit slope of $-7.7 \%$ is consistent with the range of experimentally determined isotopic fractionation factors associated with biological acetate utilization (26). 


\section{Supporting tables}

Table S1: Endospore to vegetative cell ratios for different depth intervals. The upper interval boundary was approximated to the depth of the shallowest sample analyzed for endospores $(250 \mathrm{mbsf}$ ) or the depth of the major decline of vegetative cell concentrations (350 mbsf). The lower boundary was set by the deepest endospore sample (1121 mbsf) or the sediment/basement boundary (1177 mbsf). Additionally, calculations using the endospore detection limit of $2.2 \times 10^{4}$ endospores $\mathrm{cm}^{-3}$ are provided together with calculations, using the value of the analytical blank of vegetative cells as hypothetical detection limit ( $D L$ ) for endospores (4 endospores $\mathrm{cm}^{-3}$ ).

\begin{tabular}{lll}
\hline & \multicolumn{2}{l}{ Ratio endospores/vegetative cell } \\
\cline { 2 - 3 } Interval & $\begin{array}{l}\mathrm{DL}=2.2 \times 10^{4} \\
\text { endospore } \mathrm{cm}^{-3}\end{array}$ & $\begin{array}{l}\mathrm{DL}=4 \\
\text { endospores } \mathrm{cm}^{-3}\end{array}$ \\
\hline $250 \mathrm{mbsf}-1121 \mathrm{mbsf}$ & 120 & 110 \\
$250 \mathrm{mbsf}-1177 \mathrm{mbsf}$ & 120 & 110 \\
$350 \mathrm{mbsf}-1121 \mathrm{mbsf}$ & 8200 & 7700 \\
$350 \mathrm{mbsf}-1177 \mathrm{mbsf}$ & 6500 & 6100 \\
\hline
\end{tabular}


Table S2: Potential methanogenesis rates from dissolved inorganic carbon determined in radiotracer experiments. AVG = average, StDEV = Standard deviation. Gray fields indicate average rates below the quantification limit $\left(<0.094 \mathrm{pmol}_{\mathrm{CH}} \mathrm{Cm}^{-3} \mathrm{~d}^{-1}\right)$.

\begin{tabular}{|c|c|c|c|c|c|}
\hline & Replicate 1 & Replicate 2 & Replicate 3 & & \\
\hline $\begin{array}{l}\text { Depth } \\
\text { [mbsf] }\end{array}$ & $\begin{array}{c}\text { Methane } \\
\text { production } \\
{\left[\mathrm{pmol} \mathrm{d}^{-1} \mathrm{~cm}^{-3} \text { ] }\right.}\end{array}$ & $\begin{array}{c}\text { Methane } \\
\text { production } \\
{\left[\text { pmol d } \mathrm{cm}^{-1} \text { ] }\right.}\end{array}$ & $\begin{array}{c}\text { Methane } \\
\text { production } \\
{\left[\text { pmol d } \mathrm{cm}^{-1} \text { ] }\right.}\end{array}$ & $\begin{array}{l}\text { AVG Methane } \\
\text { production } \\
{\left[\text { pmol d } \mathrm{cm}^{-1} \text { ] }\right.}\end{array}$ & $\begin{array}{l}\text { StDev Methane } \\
\text { production } \\
{\left[\mathrm{pmol} \mathrm{d}^{-1} \mathrm{~cm}^{-3} \text { ] }\right.}\end{array}$ \\
\hline 189 & 391.53 & 394.71 & 464.39 & 416.88 & 41.18 \\
\hline 206 & 27.86 & 35.62 & 4.49 & 22.65 & 16.20 \\
\hline 319 & 1.49 & 3.59 & 2.36 & 2.48 & 1.06 \\
\hline 350 & 1.08 & 2.50 & 0.88 & 1.49 & 0.88 \\
\hline 405 & 0.90 & 0.47 & 0.30 & 0.56 & 0.31 \\
\hline 412 & 0.51 & 0.98 & 0.42 & 0.63 & 0.30 \\
\hline 430 & 0.57 & 0.24 & 0.72 & 0.51 & 0.25 \\
\hline 443 & 0.18 & 0.00 & 0.00 & 0.06 & 0.10 \\
\hline 448 & 0.88 & 1.30 & 0.47 & 0.88 & 0.41 \\
\hline 476 & 1.55 & 0.53 & 0.41 & 0.83 & 0.62 \\
\hline 486 & 0.19 & 0.12 & 0.05 & 0.12 & 0.07 \\
\hline 496 & 0.15 & 0.14 & 0.05 & 0.11 & 0.06 \\
\hline 508 & 0.00 & 0.00 & 0.05 & 0.02 & 0.03 \\
\hline 538 & 0.05 & 0.25 & 0.13 & 0.14 & 0.10 \\
\hline 564 & 1.91 & 0.89 & 0.73 & 1.18 & 0.64 \\
\hline 576 & 0.00 & 0.00 & 0.05 & 0.02 & 0.03 \\
\hline 585 & 0.15 & 0.05 & 0.05 & 0.08 & 0.06 \\
\hline 605 & 0.17 & 0.14 & 0.05 & 0.12 & 0.06 \\
\hline 616 & 0.21 & 0.23 & 0.26 & 0.24 & 0.03 \\
\hline 633 & 1.30 & 1.09 & 0.71 & 1.03 & 0.30 \\
\hline 643 & 1.78 & 2.24 & 0.71 & 1.58 & 0.79 \\
\hline 693 & 0.32 & 0.45 & 0.33 & 0.37 & 0.07 \\
\hline 718 & 0.50 & 0.29 & 0.29 & 0.36 & 0.12 \\
\hline 735 & 0.64 & 0.58 & 0.17 & 0.46 & 0.26 \\
\hline 754 & 0.19 & 0.05 & 0.00 & 0.08 & 0.10 \\
\hline 775 & 0.00 & 0.00 & 0.09 & 0.03 & 0.05 \\
\hline 816 & 0.05 & 0.11 & 0.14 & 0.10 & 0.05 \\
\hline 830 & 0.00 & 0.05 & 0.05 & 0.03 & 0.03 \\
\hline 850 & 0.23 & 0.19 & 0.16 & 0.19 & 0.04 \\
\hline 864 & 0.52 & 0.47 & 0.25 & 0.41 & 0.15 \\
\hline 883 & 0.33 & 0.41 & 0.50 & 0.41 & 0.09 \\
\hline 901 & 0.20 & 0.33 & 0.16 & 0.23 & 0.09 \\
\hline 922 & 0.11 & 0.05 & 0.05 & 0.07 & 0.04 \\
\hline 940 & 0.18 & 0.00 & 0.00 & 0.06 & 0.11 \\
\hline 961 & 0.05 & 0.05 & 0.00 & 0.03 & 0.03 \\
\hline 980 & 0.17 & 0.00 & 0.00 & 0.06 & 0.10 \\
\hline 1003 & 0.00 & 0.05 & 0.00 & 0.02 & 0.03 \\
\hline 1022 & 0.14 & 0.00 & 0.00 & 0.05 & 0.08 \\
\hline 1042 & 0.00 & 0.00 & 0.05 & 0.02 & 0.03 \\
\hline 1066 & 0.00 & 0.00 & 0.00 & 0.00 & 0.00 \\
\hline 1094 & 1.96 & 2.17 & 1.86 & 2.00 & 0.16 \\
\hline 1124 & 2.66 & 1.55 & 1.51 & 1.91 & 0.65 \\
\hline 1177 & 1.12 & 1.26 & 2.11 & 1.50 & 0.53 \\
\hline
\end{tabular}

